\title{
Synthesis of the Tetraketide Lactones from the Pikromycin Biosynthetic Pathway
}

\author{
Hong-Se Oh, ${ }^{[a]}$ Ji-Suk Yun, ${ }^{[a]}$ Ki-Hyun Nah, ${ }^{[a]}$ Han-Young Kang, ${ }^{*[a]}$ and David H. Sherman ${ }^{[b]}$
}

Keywords: Polyketide / Pikromycin / Biosynthesis / Lactones / Asymmetric synthesis

Synthesis of tetraketide lactones $\mathbf{2}$ and $\mathbf{3}$, which are likely to be produced by a model pikromycin polyketide synthase (PKS), has been investigated. The tetraketide lactones with six-membered rings, $\mathbf{2 a}$ and $\mathbf{2 b}$, were synthesized successfully by the asymmetric aldol reaction, allylation, and the Reformatsky reaction. The attempted synthesis of tetraketide lactones with eight-membered rings, $\mathbf{3 a}$ and $\mathbf{3} \mathbf{b}$, led to the formation of the compounds $\mathbf{2} \mathbf{a}$ and $\mathbf{2} \mathbf{b}$. The synthesis of an- other tetraketide lactone compounds $\mathbf{3 5}$ was attempted with the hope that introducing an additional methyl group would lead to a change in thermodynamic stability. However, it produced the corresponding tetraketide lactone $\mathbf{3 4}$ with a sixmembered ring.

(๔ Wiley-VCH Verlag GmbH \& Co. KGaA, 69451 Weinheim, Germany, 2007)

\section{Introduction}

The development of the modern synthetic methods has made important contributions to not only answering the emerging questions from chemistry but also explaining a variety of phenomena originating from the biological fields. Recently, studies on natural product chemistry based on genetic techniques have enjoyed a dramatic growth. ${ }^{[1]}$ The driving force of this is mainly attributed to the power of modern organic synthesis and the fast-developing genetic knowledge and techniques. Polyketide macrolides belong to a well-studied class of compounds in natural products, and the investigation of their biosynthesis is dependent on genetic techniques. For example, erythromycin is a typical macrolide that has been a target for examining various biosynthetic pathways using the newly developed genetic concepts. ${ }^{[2]}$ Polyketide synthase (PKS), an enzyme responsible for producing erythromycin, is made up of characteristic modular structures. Studies on 6-deoxyerythronolide B polyketide synthase have made a significant contribution to expanding our understanding of the bacterial type I PKS, which is organized of modules, each of which catalyzes one cycle of elongation of the chain. ${ }^{[3]}$

Pikromycin is another polyketide macrolide that has attracted considerable attention in biosynthetic research on account of the remarkable ability of the PKS enzyme to produce this large ring-sized polyketide lactone. Pikromycin

[a] Department of Chemistry, Chungbuk National University, Cheongju, Chungbuk 361-763, Republic of Korea Fax: +82-43-267-2279

E-mail: hykang@chungbuk.ac.kr

[b] Department of Medicinal Chemistry, University of Michigan, Ann Arbor, MI 48109, USA

$\square$ Supporting information for this article is available on the WWW under http://www.eurjoc.org or from the author.
PKS is a gigantic enzyme that is involved in the synthesis of macrolide antibiotics including methymycin and pikromycin. ${ }^{[3]}$ This is fascinating because a single enzyme produces macrocyclic compounds with two different ring sizes, 12- and 14-membered rings (methymycin and pikromycin). The pikromycin PKS also possesses additional post-modification functions (i.e. glycosylation and oxidation) for the macrolides. These features make PKS an ideal system for generating a diverse range of macrolides through so-called combinatorial biosynthesis, which is a brilliant concept that involves cutting and reshuffling the genes responsible for individual biochemical transformations for the synthesis of iterating structural units. ${ }^{[4]}$ Figure 1 shows the genetic modular arrangement of the pikromycin PKS system. Whilst understanding the nature of the PKS is essential for investigating the biosynthetic pathway, the structural complexity of the macrolides has been an impediment to the progress of the biosynthetic research. Although, in principle, the concept of combinatorial biosynthesis for generating structurally new compounds by mixing and combining genetic modules is intriguing, biosynthetic research in this area has been hindered by the limited availability of the biosynthesized compounds due to the interrupted function of the resulting hybrid PKS.

A research program was, therefore, initiated with the aim of developing the systematic methods for the synthesis of the possible intermediates; particularly polyketide lactones from the pikromycin biosynthetic pathway with the view to understand further the importance of securing polyketide intermediates from the anticipated biosynthetic pathway. The structure of the products from the genetic work is so complex that we became interested in the simpler PKS system which could, in turn, generate intermediate polyketides with simpler structures. This concept has been demon- 


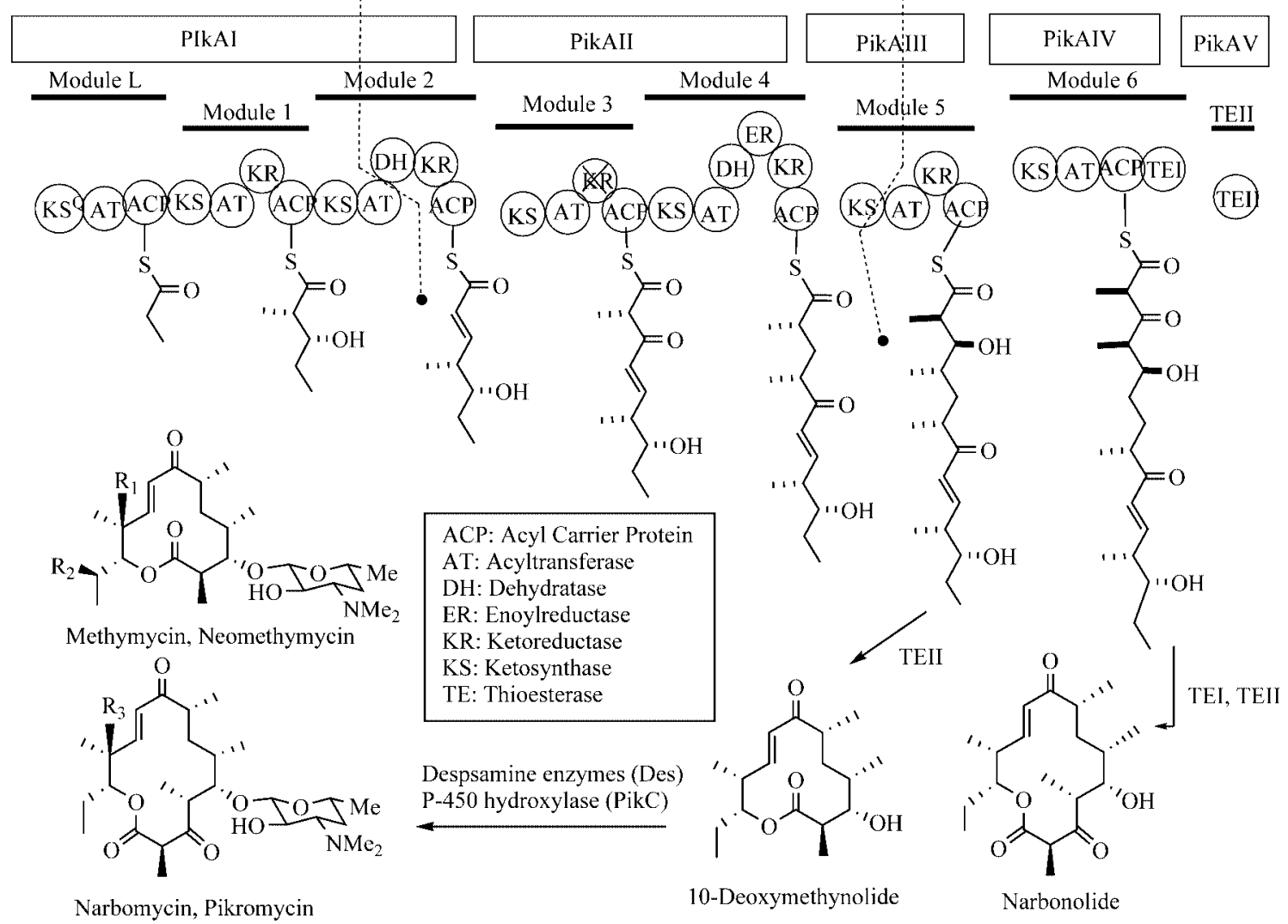

Figure 1. Modular organization of the pikromycin PKS.

strated with smaller hybrid PKS systems such as DEBS1 (DEBS = 6-deoxyerythronolide B synthase) + TE (thioesterase), ${ }^{[5]}$ or DEBS1-TE ${ }^{[6]}$ truncated version of erythromycin PKS. Both these simpler PKSs have been used extensively to examine the biosynthesis of 6-deoxyerythrolide B. These hybrid PKSs have produced the expected smaller polyketide lactones. ${ }^{[7]}$

Inspired by the simpler erythromycin PKS systems, a similar truncated version of the hybrid PKS system was designed for pikromycin biosynthesis. The model PKS system used in this study involved cutting the genes between the AT and DH domain in module 2 and between AT and KR domain in module 5 and combining the two modules. It was anticipated that this fused PKS would produce tri- and tetraketide lactones, i.e. six-membered and eight-membered lactones, as shown in Figure 2. Therefore, the hybrid model PKS could serve not only as a model system but also as a valuable tool for investigating the function and role of modules 5 and 6, which is expected to make a significant contribution to the understanding of the pikromycin PKS system. ${ }^{[8]}$

In order to achieve a combinatorial biosynthesis using a polyketide synthase, it is essential to understand the biosynthetic pathways and experiences of handling the intermediates efficiently. Therefore, the aim of this study is to develop synthetic routes to prepare polyketide lactones through the pikromycin biosynthetic pathways. In connection with the generation of a simple hybrid PKSs derived from the pikro-

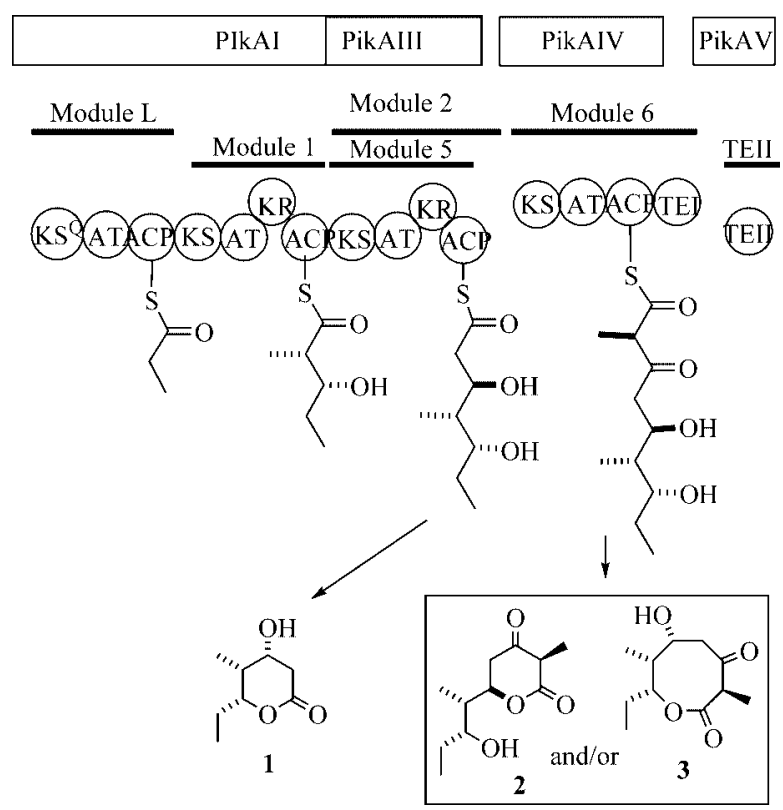

Figure 2. Model Pik PKS system for the synthetic targets. Fusion of pik AI mod::pik AIII mod 5.

mycin PKS system, the initial focus was on synthesizing the polyketide lactones $\mathbf{1}, \mathbf{2}$, and $\mathbf{3}$. The synthesis of simple sixmembered $\delta$-lactones 1 is reported previously. ${ }^{[9,10]}$ Here, we describe the results of the synthetic studies of the tetraketide lactones $\mathbf{2}$ and $\mathbf{3}$. 


\section{Results and Discussion}

The retrosynthetic analysis of the lactones shown in Scheme 1 indicates that the target tetraketide lactone $\mathbf{2}$, which mainly exists as an enol form, could be synthesized from the linear intermediate $\mathbf{A}$ through a simple consecutive two-carbon chain elongation of the intermediate, which was previously prepared during the synthesis of the triketide $\delta$ lactone $1 .{ }^{[9]}$ Because it is preferable to secure all the possible intermediate polyketide lactones for future biosynthetic research, we believed that it would be more appropriate to develop a synthetic route to prepare not only the lactones $\mathbf{2}$ and $\mathbf{3}$ but also their stereoisomers. Therefore, an attempt was made to synthesize the target lactones and their diastereomers (i.e. C5-epimers, vide infra).

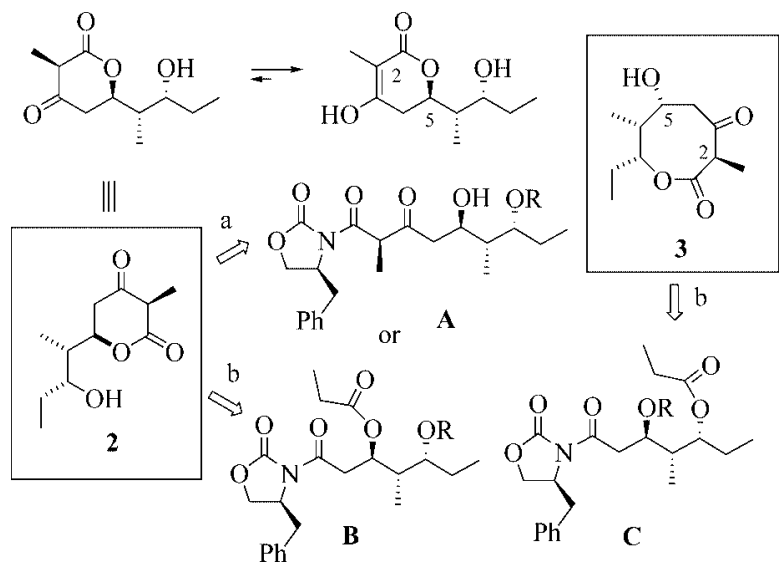

Scheme 1. Retrosynthetic scheme.

Scheme 2 shows the synthetic route according to the retrosynthetic analysis (Route a). Aldehyde $\mathbf{5}$ was obtained by the oxidation of the alcohol $4 .{ }^{[9]}$ The aldol reaction proceeded without incident to give the aldol product 7. Oxidation provided the 1,3-keto compound $\mathbf{8}$, which was hydrolyzed to the corresponding carboxylic acid. However, cyclization of the resulting carboxylic acid was unsuccessful. Because this failure might be due to the enolization of the 1,3-keto compound $\mathbf{8}$, cyclization was attempted using the aldol product 7. Cyclization was achieved successfully and oxidation with the resulting lactone provided the keto lactone 9. Unfortunately, the deprotection of the benzyl group was unsuccessful, even with various known methods. The difficulty in deprotection led us to examine other approaches for preparing the tetraketide lactones.

The synthetic route was re-analyzed and an attempt was made to devise a common route for synthesizing both tetraketide lactones $\mathbf{2}$ and $\mathbf{3}$ (a six-membered and a eight-membered lactone, respectively). Retrosynthetic analysis revealed that the paths that lead to the intermediates $\mathbf{B}$ and $\mathbf{C}$ in Scheme 1 (which would lead to compounds $\mathbf{2}$ and $\mathbf{3}$, respectively, route b) would have the advantage of employing similar intermediates for the synthesis of both tetraketide lactones. Moreover, the synthesis of a similar tetraketide lactone has been reported (Scheme 3). ${ }^{[11]}$ An intramo-

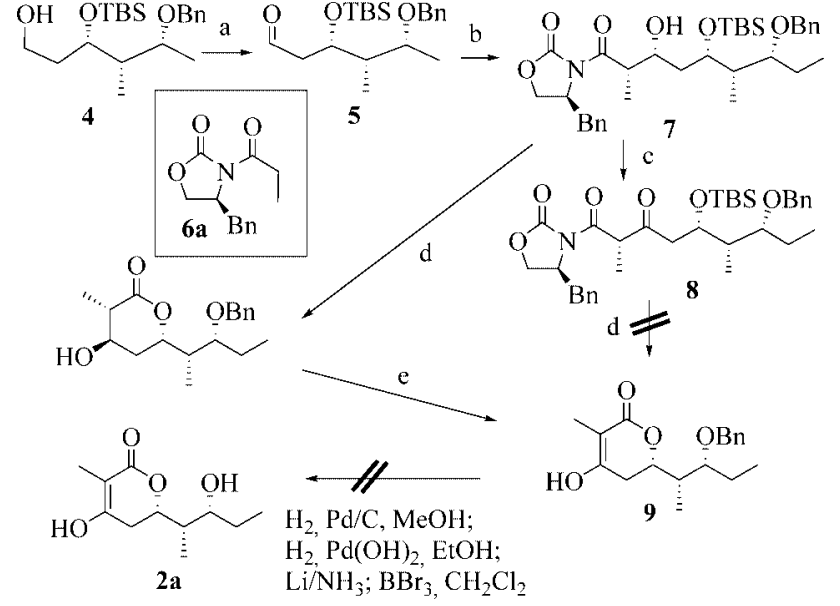

Scheme 2. Reagents and conditions: (a) Swern Oxidation (83\%) (b) 6a, $\mathrm{Bu}_{2} \mathrm{OTf}, \mathrm{Et}_{3} \mathrm{~N}, \mathrm{CH}_{2} \mathrm{Cl}_{2}(68 \%)$ (c) Dess-Martin periodinane (DMP), $\mathrm{CH}_{2} \mathrm{Cl}_{2}$ (80\%) (d) (1) $\mathrm{H}_{2} \mathrm{O}_{2}$, LiOH (2) $1 \mathrm{M} \mathrm{HCl} / \mathrm{THF}, 5: 1$ (68\%, two steps) (e) DMP, $\mathrm{CH}_{2} \mathrm{Cl}_{2}(85 \%)$.

lecular Claisen condensation was employed for the efficient construction of the six-membered lactones for a similar tetraketide lactone.

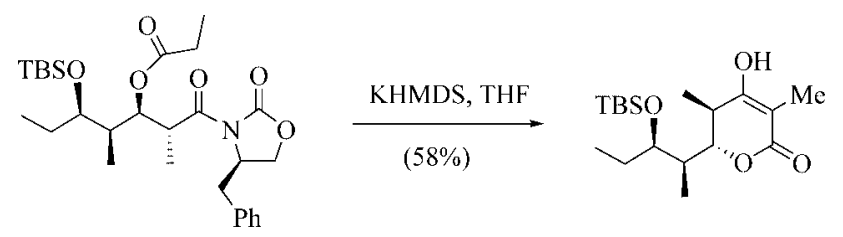

Scheme 3. An example of the Claisen condensation approach.

The tetraketide lactones synthesized in this study could be achieved using a similar procedure because the only difference between the tetraketide lactone in Scheme 3 and the target lactone 2a is the existence of a methyl group. It was believed that this synthesis would be quite straightforward. Scheme 4 summarizes the synthesis according to the Claisen condensation route.

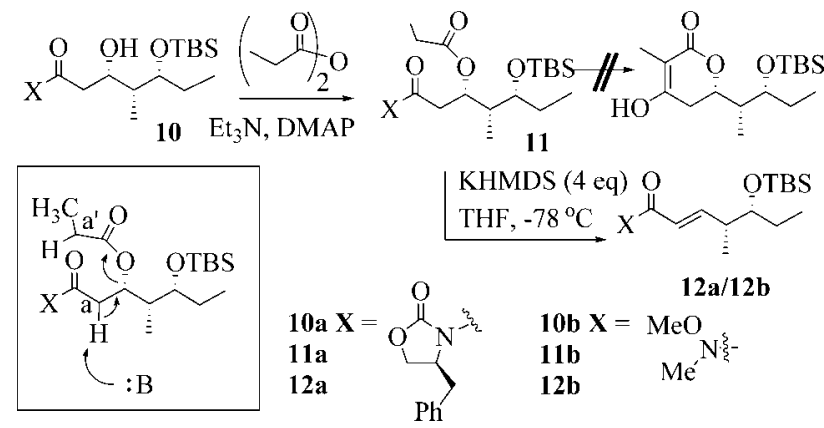

Scheme 4. Attempt to synthesize the tetraketide lactone according to the Claisen condensation route.

The acylated product 11a, which was prepared by the propionation of the previously reported alcohol 10, was treated with a strong base (KHMDS) with the aim of producing the desired lactone. However, the product formed is believed to be the $\alpha, \beta$-unsaturated compound 12a. The 
anion formed by proton abstraction at the $\alpha$ position can lead to the elimination of the $\mathrm{EtCO}_{2}$ group (Scheme 4). The absence of a methyl group at the $\alpha$ position created a difference in the course of the reaction. Hoping that the acidity of the $\alpha$-proton might be altered by changing the chiral auxiliary with other group, the oxazolidinone moiety was switched to the Weinreb amide (10b). However, this change did not lead to the production of the desired lactone. The formation of the elimination product 12b was observed. Therefore, it was necessary to modify the synthetic route. The use of the intramolecular samarium(II) iodide-mediated Reformatsky reaction to produce various cyclic products including six- and eight-membered rings was considered (Scheme 5). ${ }^{[12]}$ The intramolecular Reformatsky reaction mediated by samarium(II) iodide has been used successfully by many researchers, including Molander and $\mathrm{Mu}-$ kaiyama, to prepare cyclic products.

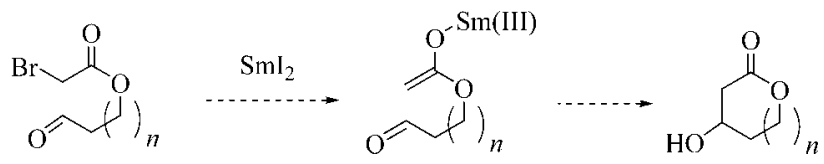

Scheme 5. Intramolecular $\mathrm{SmI}_{2}$-mediated Reformatsky reaction.

The samarium(II) iodide-mediated intramolecular Reformatsky reaction was used to synthesize the desired tetraketide lactones 2a and $\mathbf{2 b}$, as summarized in Scheme 6. Although the biosynthetic mechanism suggests compound $\mathbf{2 b}$ to be the expected product with the correct stereochemistry, a decision was made to synthesize both epimers for the future biosynthetic studies.

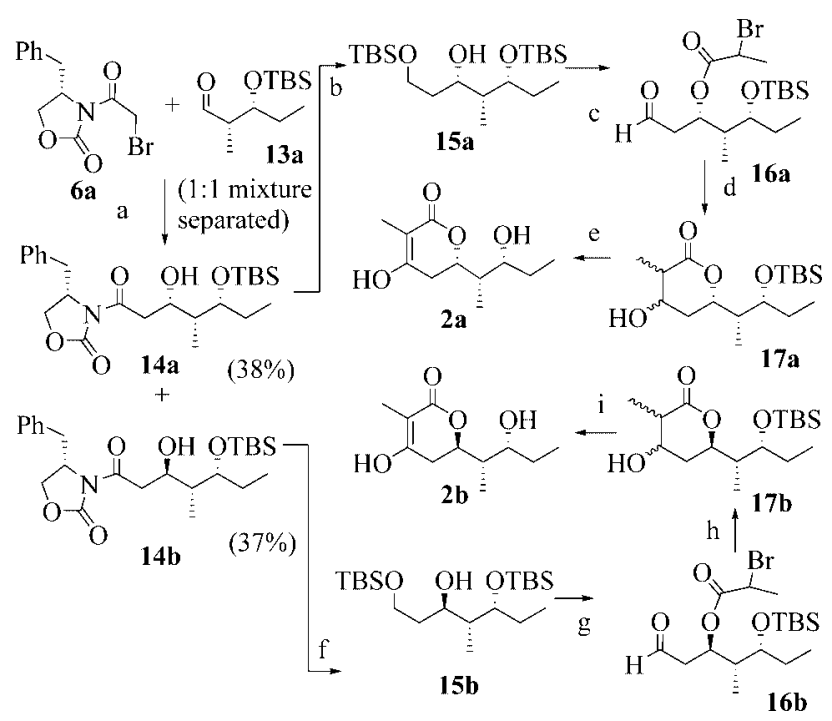

Scheme 6. Reagents and conditions: (a) ref. ${ }^{[9]}\left[\mathrm{SmI}_{2}, \mathrm{THF},-78^{\circ} \mathrm{C}\right]$ (b) (1) $\mathrm{LiBH}_{4}, \mathrm{H}_{2} \mathrm{O}(78 \%$ ) (2) imidazole, TBSCl (97\%) (c) (1) $\mathrm{CH}_{3} \mathrm{CHBrCOOH}$, DCC, DMAP $(96 \%)$ (2) CSA(cat.), $\mathrm{MeOH}$ (63\%) (3) DMP (72\%) (d) $\mathrm{SmI}_{2},-78{ }^{\circ} \mathrm{C}$ (24:1 selectivity, 59\%) (e) (1) DMP $(68 \%),(2) \mathrm{HF} / \mathrm{CH}_{3} \mathrm{CN}(74 \%)$ (f) (1) $\mathrm{LiBH}_{4}, \mathrm{H}_{2} \mathrm{O}(70 \%)$, (2) imidazole, TBSCl (99\%) (g) (1) $\mathrm{CH}_{3} \mathrm{CHBrCOOH}, \mathrm{DCC}$, DMAP (97\%) (2) CSA(cat.), MeOH (88\%) (3) DMP (89\%) (h) $\mathrm{SmI}_{2}, \mathrm{THF},-78{ }^{\circ} \mathrm{C}(20: 1$ selectivity, $60 \%)$ (i) (1) DMP (68\%) (2) $\mathrm{HF} / \mathrm{CH}_{3} \mathrm{CN}(70 \%)$.
The asymmetric intermolecular Reformatsky reaction mediated by samarium(II) iodide ${ }^{[13]}$ provided the epimeric aldol products 14a and $\mathbf{1 4 b}$ (with no diastereoselectivity). After chromatographic separation, the aldol product 14a (a series) was converted to a TBS-protected triol 15a, by reduction followed by silylation of the newly formed primary hydroxy group. The required ester for the intramolecular Reformatsky reaction was prepared by esterification with DCC. The hydroxy group was deprotected under acidic conditions, and the aldehyde 16a, which is a precursor for cyclization, was secured. The key samarium(II) iodide-mediated intramolecular Reformatsky reaction was performed successfully $\left(\mathrm{SmI}_{2}, \mathrm{THF},-78^{\circ} \mathrm{C}\right)$. The resulting lactone (ca. 24:1 diastereoselectivity) was oxidized and deprotected to afford the desired tetraketide lactone 2a. The epimeric lactone $\mathbf{2 b}$ was synthesized by an identical reaction sequence starting from the aldol product $\mathbf{1 4 b}$ (b series). Therefore, the Reformatsky reaction mediated by samarium(II) iodide with aldehyde $16 \mathrm{~b}$ yielded the lactone $\mathbf{1 7 b}$ (diastereoselectivity $=20: 1$ ). Oxidation followed by deprotection produced the desired tetraketide lactone $\mathbf{2} \mathbf{b}$.

The synthesis of the eight-membered tetraketide lactones 3 was attempted after successfully synthesizing the sixmembered ring tetraketide lactones $\mathbf{2 a}$ and $\mathbf{2 b}$. The plan was to use the same protected triol intermediate, which was thought to give both target tetraketide lactones $\mathbf{2}$ and $\mathbf{3}$ depending on which hydroxy group was chosen for acylation. The asymmetric Reformatsky reaction of compound $\mathbf{6 a}$ with the aldehyde 13b gave a 13:1 mixture of the compounds 18a and $\mathbf{1 8 b}$ (Scheme 7). ${ }^{[14]}$ The same reaction with compound $\mathbf{6 b}$ provided a lower ratio (3:1) as a consequence of a mismatched pair. After protecting the free hydroxy group at the 3-position of the major isomer 18a with a silyl group, the chiral auxilary was removed by reduction with $\mathrm{LiBH}_{4}$. The resulting primary alcohol was protected with the TBS group. The secondary alcohol 19a was obtained by deprotecting the PMB group. It was expected that this alcohol would be converted into the desired eight-membered lactones $\mathbf{3 a}$.

The free secondary hydroxy group of compound 19a was esterified with 2-bromopropanoic acid. The removal of the TBS group followed by oxidation gave the aldehyde 20a, which was subjected to the key samarium(II) iodide-mediated intramolecular Reformatsky reaction. ${ }^{1} \mathrm{H}$ NMR spectral analysis showed that the Reformatsky reaction gave the eight-membered lactone 21a as a mixture of two diastereomers with a ratio of $7: 1$. The precise stereochemistry of the products in the mixture was not determined. The mixture was further oxidized to produce compound 22a as an 8:1 mixture with a C-2 stereocenter. Therefore, the intramolecular Reformatsky reaction was expected to be highly stereoselective with respect to the chiral C-3 atom. It was hoped that the stereochemistry at C-2 would be controlled by the thermodynamic stability. The only remaining step to complete the synthesis of the eight-membered lactone 3a was the deprotection of the hydroxy group. Surprisingly, although understandable under the deprotection condition $\left(\mathrm{HF} / \mathrm{CH}_{3} \mathrm{CN}\right)$, the protected lactone 22a was converted into 


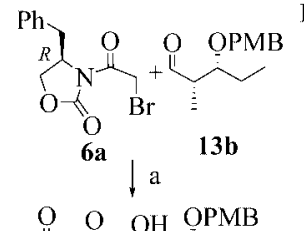

Ph $=O \quad O$ OPMB $\mathrm{O}$ OH OPMB

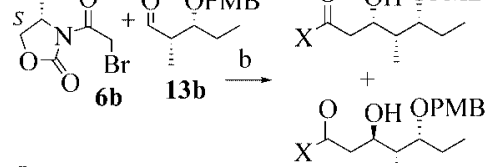

$\underbrace{\mathrm{O}}_{\mathrm{Ph}_{\mathrm{c}, \mathrm{d}}} \underbrace{\mathrm{O}}_{\mathbf{1 8 a}}$

O 少 $\mathrm{X}=\underbrace{\mathrm{O}}_{\mathrm{Ph}^{\mathrm{O}} \mathrm{N}^{-\varepsilon^{2}}}$<smiles>C=CCCC1OC(=O)C(C)C(=O)CC(O)CC1CC=C</smiles>

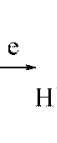<smiles>CCC</smiles>
OTBS $\mathrm{O}$
$18 b$

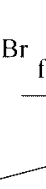

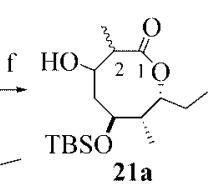
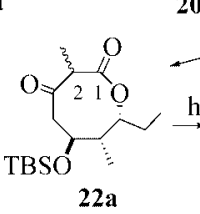

$\underbrace{21 a}_{(12}$

2a
Scheme 7. Reagents and conditions: (a) $\mathrm{SmI}_{2}, \mathrm{THF},-78^{\circ} \mathrm{C}(65 \%)$ $[d r=13: 1(\mathbf{1 8 a} / \mathbf{1 8 b})]$ (b) $\mathrm{SmI}_{2}, \mathrm{THF},-78{ }^{\circ} \mathrm{C}(74 \%)[d r=3: 1$ (a:b) $]$ (c) 2,6-Lutidine, TBSOTf (82\%) (d) (1) $\mathrm{LiBH}_{4}, \mathrm{H}_{2} \mathrm{O}(94 \%)$ (2) imidazole, TBSCl (95\%) (3) DDQ (74\%) (e) (1) $\mathrm{CH}_{3} \mathrm{CHBrCOOH}$, DCC (97\%) (2) CSA(cat.), $\mathrm{MeOH}(88 \%)$ (3) DMP (91\%) (f) $\mathrm{SmI}_{2}$, $-78{ }^{\circ} \mathrm{C}(72 \%, 7: 1$ mixture) (g) DMP (88\%, 8:1 mixture) (h) HF/ $\mathrm{CH}_{3} \mathrm{CN}(58 \%)$.

the tetraketide $\delta$-lactone 2a. The attempted deprotection of the lactone removed the silyl group and caused the translactonization to produce the lactone $\mathbf{2 a}$, which was identical to the lactone prepared previously (Scheme 6). This translactonization is likely driven by the thermodynamic stability. ${ }^{[15]}$ Desilylation 22a under acidic conditions $(\mathrm{HCl}$, $\mathrm{AcOH}$, or CSA) also tried but failed to produce the desired lactone 3a. Only decomposition was observed. The lactone having the PMB-protected hydroxy group (22c) was also prepared to find out any difference upon changing the protecting group. However, only $\mathbf{2 a}$ was formed under the standard deprotection condition (DDQ, $\mathrm{CH}_{2} \mathrm{Cl}_{2}: \mathrm{H}_{2} \mathrm{O}=10: 1$, $0{ }^{\circ} \mathrm{C}$ ). The structure of the lactone $\mathbf{2 a}$ was confirmed by ${ }^{1} \mathrm{H}$ NMR, ${ }^{13} \mathrm{C}$ NMR, and ${ }^{1} \mathrm{H}-{ }^{1} \mathrm{H}$ COSY spectra.

It was believed that it would be preferable to secure the possible diastereomers of the target lactones for the future biosynthetic studies. Therefore, an attempt was made to synthesize the diastereomeric lactone $\mathbf{3 b}$. The main interest in this attempt was to determine the effect of the stereochemistry at the C-5 position. The synthesis of the epimeric tetraketide lactone $\mathbf{3 b}$ was initiated using a modified procedure from that used in the attempted synthesis of $\mathbf{3 a}$. It was hoped that the hydroxy group with the epimeric stereochemistry at C-5 would lead to an eight-membered ring structure or render the resulting oxygen-centered anion, which had been formed by the deprotection of the silyl group, unable to attack the carbonyl carbon of the lactone. At the time of performing this synthesis, a more practical synthetic route was adopted to prepare the required precursors for the key Reformatsky reaction (Scheme 8; b series). In other words, the allylation reaction was used instead of the aldol reaction based on the Evans' chiral auxiliaries. Although, the conditions for producing the desired allylated product $\mathbf{2 3 b}$ exclusively were determined, ${ }^{[10]}$ a simple, practical, substrate-controlled approach was adopted for the synthesis of compound $\mathbf{2 3 b}$. The aldehyde $\mathbf{1 3 b}$ was allylated to give a 3:2 mixture of compounds 23a and 23b. The undesired isomer 23a was recycled to the desired isomer $\mathbf{2 3 b}$ by oxidation followed by reduction. The allylated alcohol 23b was obtained in $40 \%$ yield after this oxidation-reduction sequence. The alcohol $\mathbf{2 3 b}$ was converted into the aldehyde 25b through protection of the free hydroxy and oxidative cleavage of the vinyl group. The aldehyde $\mathbf{2 5 b}$ was then reduced, and the resulting primary hydroxy group was protected with the TBS group. The PMB ether was deprotected and acylated. After regenerating the primary hydroxy group followed by oxidation, the key intramolecular Reformatsky reaction was performed using the aldehyde $\mathbf{2 0 b}$. The desired eight-membered ring was formed as a mixture of two diastereomers with a ratio of 1:2. The two products are believed to be the diastereomeric mixture of C-2 (and C-3) isomers. Furthermore, although not precisely identified, two diastereomeric products appeared to be mainly C-2 stereoisomers. This was supported by the fact that the $\beta$ keto ester $\mathbf{2 2} \mathbf{b}$, which was formed by the oxidation of compound $\mathbf{2 1 b}$, maintained a similar isomeric ratio (2:1). Un-

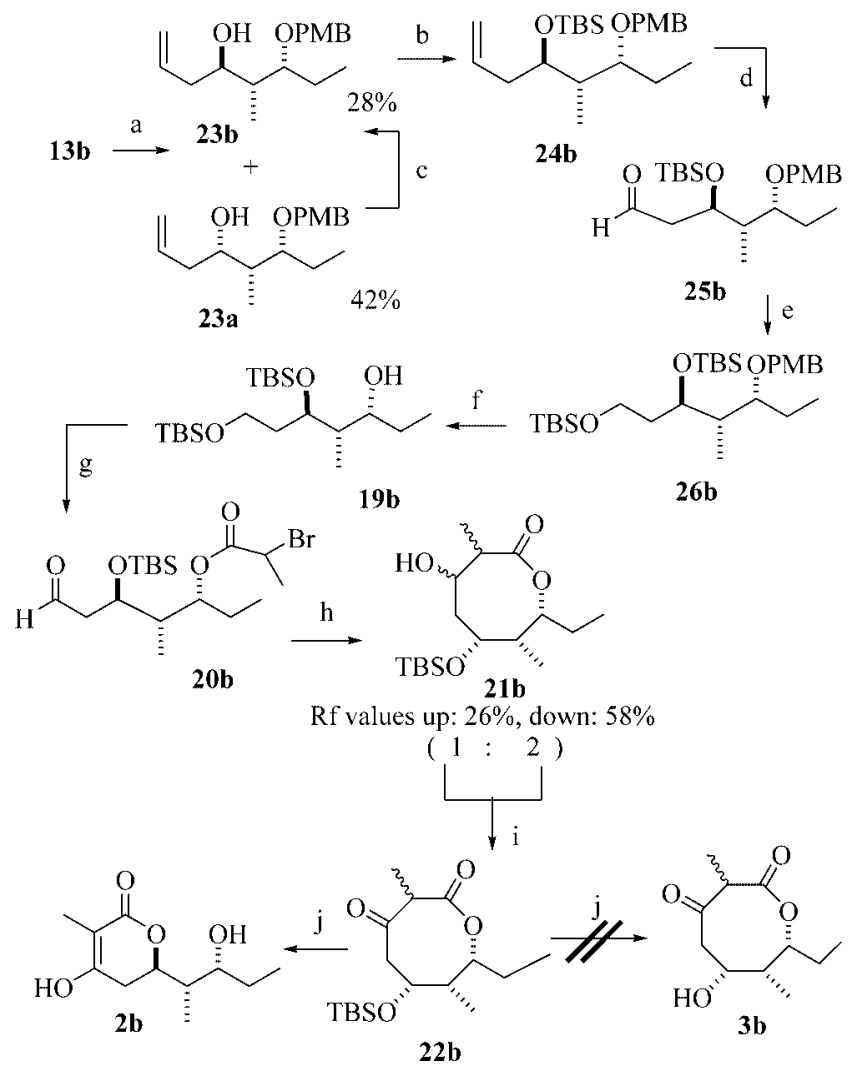

Scheme 8. Reagents and conditions: (a) In, allyl bromide, THF: $\mathrm{H}_{2} \mathrm{O}=1: 1(70 \%)$ (b) TBSOTf, 2,6-lutidine, $0{ }^{\circ} \mathrm{C}, \mathrm{CH}_{2} \mathrm{Cl}_{2}$ (98\%) (c) (1) DMP, (2) $\mathrm{NaBH}_{4}(2: 3$ mixture) (recycled, 40\%) (d) (1) $\mathrm{NMO}^{-\mathrm{OsO}_{4}}$ (2) $\mathrm{NaIO}_{4}\left(t \mathrm{BuOH}: \mathrm{THF}: \mathrm{H}_{2} \mathrm{O}=10: 2: 1\right)(92 \%$, two steps) (e) (1) $\mathrm{NaBH}_{4}, \mathrm{MeOH}, 0{ }^{\circ} \mathrm{C}(94 \%)$ (2) TBSOTf, 2,6-lutidine, $0{ }^{\circ} \mathrm{C}, \mathrm{CH}_{2} \mathrm{Cl}_{2}(99 \%)$ (f) DDQ, DCM:pH 7 buffer $=10: 1(96 \%)(\mathrm{g})$ (1) $\mathrm{CH}_{3} \mathrm{CHBrCOOH}, \mathrm{DMAP}(\mathrm{cat}), \mathrm{DCC}(95 \%)$ (2) $\mathrm{CSA}, \mathrm{MeOH}$ (91\%) (3) DMP (90\%) (h) $\mathrm{SmI}_{2}, \mathrm{CH}_{2} \mathrm{Cl}_{2}(84 \%, 2: 1$ mixture) (i) DMP $\left(96 \%, 2: 1\right.$ mixture) (j) $\mathrm{HF} / \mathrm{CH}_{3} \mathrm{CN}$, room temp. (97\%). 
fortunately, it was found that deprotection of the silyl group of 22b did not lead to isolate the desired eight-membered lactone $\mathbf{3 b}$ but instead, produced the tetraketide lactone $\mathbf{2 b}$. Therefore, the translactonization to an eight-membered lactone by attacking the anionic oxygen atom, which was formed by deprotecting of the ester carbonyl group, was favored.

We were unable to obtain the desired eight-membered lactones with free hydroxy groups $\mathbf{3} \mathbf{a}$ and $\mathbf{3 b}$, even though the synthesis of eight-membered lactone rings has been successful using the samarium(II) iodide-promoted intramolecular Reformatsky reaction. As a result, a decision was made to further examine the factors that influence the stability. We have experienced that the existence of a methyl group can make a critical difference in acidity that can enable the desired Claisen condensation to proceed. Therefore, it would be interesting to check the behavior of a similar structure in cyclization with the presence of the methyl group at the C-4 position. A lactone with a similar structure to the compound 2 could be prepared with an additional methyl group at the C-4 position. Scheme 9 shows the synthetic pathway of the lactone. The aldol reaction was performed with compounds $\mathbf{2 7}$ and $\mathbf{1 3 b}$ to provide compound 28. This aldol product $\mathbf{2 8}$ was converted into the fully protected triol 29 in a straightforward manner. After deprotection of the PMB group, the same procedure as that used in the previous attempt to prepare compound $\mathbf{3}$ was applied. The aldehyde 31, which is the precursor for the Reformatsky reaction, was treated with samarium(II) iodide in THF. The desired eight-membered lactone (with a methyl group at C-4) 32 was formed efficiently as a diastereomeric mixture with a ratio of 5:1.
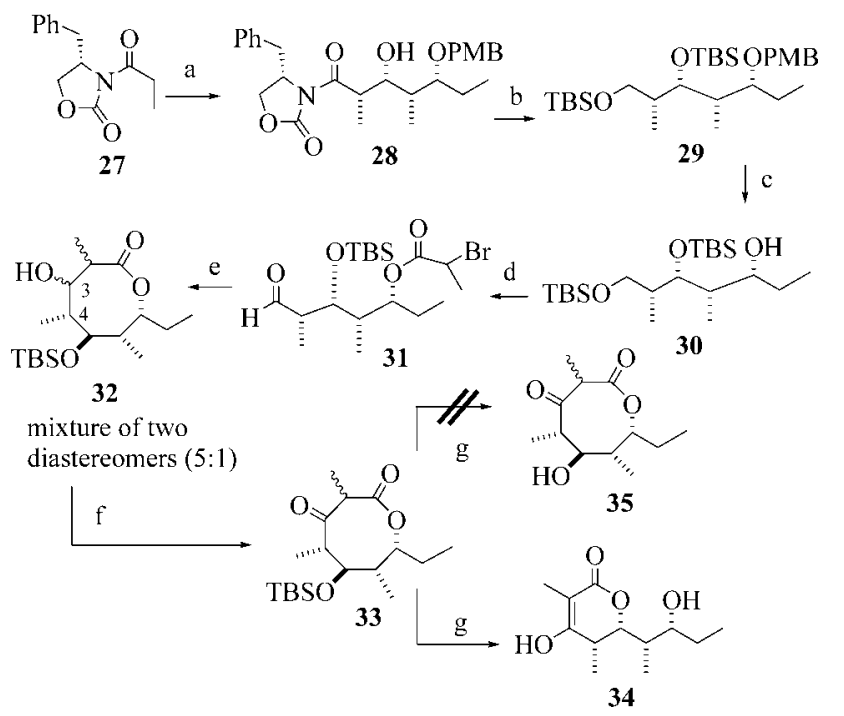

Scheme 9. Reagents and conditions: (a) 13b, $\mathrm{Bu}_{2} \mathrm{BOTf}, \mathrm{Et}_{3} \mathrm{~N}(80 \%)$ (b) (1) 2,6-lutidine, TBSOTf, DCM, $0{ }^{\circ} \mathrm{C}(89 \%)$ (2) $\mathrm{LiAlH}_{4}, \mathrm{H}_{2} \mathrm{O}$ (86\%) (3) 2,6-lutidine, TBSOTf (94\%) (c) DDQ, DCM:pH 7 buffer $=10: 1(99 \%)$ (d) (1) $\mathrm{CH}_{3} \mathrm{CHBrCOOH}, \operatorname{DMAP}($ cat $), \mathrm{DCC}$, $\mathrm{CH}_{2} \mathrm{Cl}_{2}, 0{ }^{\circ} \mathrm{C}(89 \%)$ (2) $\mathrm{CSA}, \mathrm{MeOH}, 0{ }^{\circ} \mathrm{C}(85 \%)$ (3) DMP, $\mathrm{CH}_{2} \mathrm{Cl}_{2}(91 \%)$ (e) $\mathrm{SmI}_{2}, \mathrm{THF},-78^{\circ} \mathrm{C}(62 \%)$ (f) $\mathrm{DMP}, \mathrm{CH}_{2} \mathrm{Cl}_{2}$, room temp. $(77 \%)(\mathrm{g}) \mathrm{HF}, \mathrm{CH}_{3} \mathrm{CN}(69 \%)$.
The major isomer of $\mathbf{3 2}$ was oxidized to a keto ester $\mathbf{3 3}$ using Dess-Martin periodinane to give a mixture of diastereomers (2:1, C-2 isomers). Deprotection of the TBS ether also afforded the $\delta$-lactone $\mathbf{3 4}$ instead of the desired $\xi$-lactone 35 . The hydroxy group of compound $\mathbf{3 2}$ was deprotected and treated with HF in order to determine the effect of the keto group. In this case, the corresponding $\delta$ lactone was also formed but the formation of the eightmembered lactone was not observed.

\section{Conclusions}

The overall aim of this study was to synthesize the intermediates and products to investigate various biosynthetic pathways. The main focus was on developing synthetic routes to prepare polyketide lactones, which are involved in the pikromycin biosynthetic pathway. A model PKS system was devised to simplify the investigation. This study examined the synthetic routes for the simpler tetraketide lactones with the six- or eight-membered rings anticipated by this model PKS. The routes were developed based on an identical key intermediate used to synthesize both tetraketide lactones with six- and eight-membered rings. The tetraketide lactones $\mathbf{2 a}$ and $\mathbf{2 b}$ with six-membered rings were synthesized efficiently utilizing the asymmetric aldol reaction and the samarium(II) iodide-mediated Reformatsky reaction as the key reactions. The formation of eight-membered lactone derivatives was also successfully achieved using the samarium(II) iodide-mediated Reformatsky reactions. Therefore, a synthetic route for the tetraketide lactone derivatives with eight-membered rings has been developed. However, the synthesis of the final target tetraketide lactones with a free hydroxy group was unsuccessful. The hydroxy lactones with an eight-membered ring, which were obtained from the final deprotection of the silyl groups, spontaneously converted into the tetraketide lactones 2a and $\mathbf{2 b}$ prepared previously. This indicates that the tetraketide hydroxy lactones with six-membered ring are thermodynamically more stable than those with eight-membered rings. The results of this study strongly indicate that the model PKS would produce only the tetraketide lactones with six-membered rings from the future incubation study. The eight-membered hydroxy lactone with an additional methyl group was also transformed to the corresponding six-membered lactone $\mathbf{3 4}$. This confirms the stability of the tetraketide lactones with six-membered rings, which is in contrast to the corresponding lactones with eight-membered rings.

The results from this synthetic investigation are expected to provide important information for the future biosynthetic research with the model PKS. We are planning to carry out an incubation study with the model PKS to elucidate the pikromycin biosynthetic mechanisms. The tetraketide lactones prepared in this study will facilitate the investigation by resolving the difficulty in identifying the key intermediates formed by the model PKS. This synthetic study would also provide valuable experience and knowledge to 
prepare related and more complex polyketide lactones from the pikromycin biosynthetic pathway. Further synthetic investigations into more complicated polyketide lactones will be reported in the future.

\section{Experimental Section}

${ }^{1} \mathrm{H}$ NMR and ${ }^{13} \mathrm{C}$ NMR spectra were recorded with a Bruker DPX-300 and Bruker Avance 500 NMR Spectrometer. The chemical shifts are reported in ppm on scale downfield from TMS, and signal patterns are indicated as follows: s, singlet; $d$, doublet; $t$, triplet; m, multiplet; br, broad peak. IR spectra were recorded with a JASCO FT/IR-300E. Optical rotations were measured by JASCO DIP-1000 digital polarometer in solution in a 1-dm cell. Mass spectra (and HRMS) were obtained with a VG AUTOSPEC Ultma GC/MS system using direct insertion probe (DIP) and electronimpact method $(\mathrm{EI}, 70 \mathrm{eV})$. All reagent and solvents were reagent grade and used without further purification unless specified otherwise. Technical grade ethyl acetate, hexane, and pentane used for column chromatography were distilled prior to use. Tetrahydrofuran (THF) and diethyl ether, when used as solvents for reactions, were freshly distilled from sodium/benzophenone ketyl. Dimethylformamide (DMF) was stored over $4-\AA$ molecular sieves, and triethylamine was distilled before use. Flash chromatography was carried out on Woelm 32-64 $\mu \mathrm{m}$ silica packed in glass columns. ${ }^{[16]}$

(3S,4R,5R)-1,5-Bis(tert-butyldimethylsilyloxy)-4-methyl-3-heptanol (15a): Distilled water $(41 \mu \mathrm{L}, 2.3 \mathrm{mmol})$ was added to a solution of ( $4 S, 3^{\prime} S, 4^{\prime} R, 5^{\prime} R$ )-4-benzyl-3-[5' -(tert-butyldimethylsilyloxy)-3' -hydroxy-4' -methylheptanoyl]-2-oxazolidinone (14a) ${ }^{[9]}$ (689 mg, $1.53 \mathrm{mmol})$ in diethyl ether $(5 \mathrm{~mL})$. After the solution was cooled to $0{ }^{\circ} \mathrm{C}$, lithium borohydride $(1.10 \mathrm{~mL}$ of a $2.0 \mathrm{~m}$ solution in THF, $2.30 \mathrm{mmol}$ ) was added slowly with stirring. After $10 \mathrm{~min}$, the temperature of the solution was raised to room temperature, and stirred for additional $2 \mathrm{~h}$. The reaction was terminated with addition of aqueous $\mathrm{NaOH}$ solution $(1.0 \mathrm{M}, 10 \mathrm{~mL})$ and extracted with diethyl ether $(3 \times 10 \mathrm{~mL})$. After the organic layer was washed with saturated sodium chloride solution $(20 \mathrm{~mL})$, the ethereal solution was dried $\left(\mathrm{MgSO}_{4}\right)$ and concentrated. Purification of the residue by flash chromatography (hexane/EtOAc, 2:1) provided the desired diol as a colorless liquid (329 mg, 78\%). IR (thin film): $\tilde{v}=$ 3387, 2957, 1641, 1462, 1256, $1057 \mathrm{~cm}^{-1}$. ${ }^{1} \mathrm{H}$ NMR $(300 \mathrm{MHz}$, $\left.\mathrm{CDCl}_{3}\right): \delta=3.92(\mathrm{dt}, J=9.8,2.7 \mathrm{~Hz}, 1 \mathrm{H}, \mathrm{CHOSi}), 3.74(\mathrm{~m}, 3 \mathrm{H}$, $\left.\mathrm{CH}_{2} \mathrm{OH}, \mathrm{CHOH}\right), 3.51\left(\mathrm{~s}, 2 \mathrm{H}, \mathrm{CH}_{2} \mathrm{OH}, \mathrm{CHOH}\right), 1.75(\mathrm{~m}, 1 \mathrm{H}$, $\left.\mathrm{CHCH}_{3}\right), 1.50\left(\mathrm{~m}, 4 \mathrm{H}, \mathrm{CH}_{2} \mathrm{CHOH}, \mathrm{CH}_{2} \mathrm{CH}_{3}\right), 0.85(\mathrm{~d}, J=3.6 \mathrm{~Hz}$, $\left.3 \mathrm{H}, \mathrm{CHCH}_{3}\right), 0.83\left[\mathrm{~s}, 9 \mathrm{H}, \mathrm{SiC}\left(\mathrm{CH}_{3}\right)_{3}\right], 0.76(\mathrm{t}, J=7.3 \mathrm{~Hz}, 3 \mathrm{H}$, $\left.\mathrm{CH}_{2} \mathrm{CH}_{3}\right), 0.03\left[\mathrm{~s}, 6 \mathrm{H}, \mathrm{Si}\left(\mathrm{CH}_{3}\right)_{2}\right] \mathrm{ppm} .{ }^{13} \mathrm{C} \mathrm{NMR}(75 \mathrm{MHz}$, $\left.\mathrm{CDCl}_{3}\right): \delta=79.2,75.5,62.2,40.5,37.4,27.9,27.0,18.6,10.4,6.8$, $-3.1,-4.0$ ppm. $[a]_{\mathrm{D}}^{26.2}=+19.7\left(c=1.61, \mathrm{CHCl}_{3}\right)$. MS (EI): $\mathrm{m} / \mathrm{z}$ $(\%)=276\left[\mathrm{M}^{+}\right], 219,202,175,145,134,117,109,77,71,68(100)$, 58. HRMS: $m / z$ calcd. for $\mathrm{C}_{14} \mathrm{H}_{32} \mathrm{O}_{3} \mathrm{Si}$ : 276.2120, found 276.2117 .

The diol (329 mg, $1.19 \mathrm{mmol}$ ) obtained above was dissolved in $\mathrm{CH}_{2} \mathrm{Cl}_{2}(4 \mathrm{~mL})$. To this solution was added a solution of imidazole (122 mg, $1.79 \mathrm{mmol})$ and tert-butyldimethylsilyl chloride $(215 \mathrm{mg}$, $1.43 \mathrm{mmol})$ in $\mathrm{CH}_{2} \mathrm{Cl}_{2}(1 \mathrm{~mL})$ at $0{ }^{\circ} \mathrm{C}$ under nitrogen. After it was stirred for $10 \mathrm{~min}$ at $0{ }^{\circ} \mathrm{C}$, the solution was warmed to room temperature and stirred for additional $1 \mathrm{~h}$ at room temperature. After the reaction was completed, aqueous saturated $\mathrm{NH}_{4} \mathrm{Cl}(5 \mathrm{~mL})$ was added and the mixture was extracted with $\mathrm{CH}_{2} \mathrm{Cl}_{2}(3 \times 10 \mathrm{~mL})$. The organic layer was separated, dried $\left(\mathrm{MgSO}_{4}\right)$, and concentrated. $\mathrm{Pu}$ rification of the residue by flash chromatography (hexan/EtOAc, 10:1) offered the desired TBS-protected alcohol 15a (453 mg, 97\%) as a colorless oil. IR (film): $\tilde{v}=3453,2957,2857,1641,1471,1389$, 1361, $1255 \mathrm{~cm}^{-1} .{ }^{1} \mathrm{H}$ NMR (300 MHz, $\left.\mathrm{CDCl}_{3}\right): \delta=3.88(\mathrm{~m}, 1 \mathrm{H}$, $\mathrm{CHOH}), 3.65-3.80\left(\mathrm{~m}, 3 \mathrm{H}, \mathrm{CH}_{2} \mathrm{OSi}, \mathrm{CHOSi}\right), 3.25$ (s, $1 \mathrm{H}$, $\mathrm{CHOH}), 1.68\left(\mathrm{~m}, 1 \mathrm{H}, \mathrm{CHCH}_{3}\right), 1.58-1.62\left(\mathrm{~m}, 2 \mathrm{H}, \mathrm{CH}_{2} \mathrm{CHOH}\right)$, $1.51\left(\mathrm{~m}, 2 \mathrm{H}, \mathrm{CH}_{2} \mathrm{CH}_{3}\right), 0.86\left[\mathrm{~m}, 21 \mathrm{H}, \mathrm{SiC}\left(\mathrm{CH}_{3}\right)_{3}, \mathrm{SiC}\left(\mathrm{CH}_{3}\right)_{3}\right.$, $\left.\mathrm{CHCH}_{3}\right] 0.78\left(\mathrm{t}, J=7.4 \mathrm{~Hz}, 3 \mathrm{H}, \mathrm{CH}_{2} \mathrm{CH}_{3}\right), 0.03$ [s, $12 \mathrm{H}, \mathrm{Si}-$ $\left.\left(\mathrm{CH}_{3}\right)_{2}, \mathrm{Si}\left(\mathrm{CH}_{3}\right)_{2}\right] \mathrm{ppm} .{ }^{13} \mathrm{C} \mathrm{NMR}\left(75 \mathrm{MHz}, \mathrm{CDCl}_{3}\right): \delta=77.6$, $72.9,61.9,40.4,37.4,27.2,25.9,25.9,18.2,18.0,9.8,7.1,-3.8$, $-4.6,-5.5 \mathrm{ppm} .[\alpha]_{\mathrm{D}}^{27.6}=+8.1\left(c=1.15, \mathrm{CHCl}_{3}\right) . \mathrm{MS}(\mathrm{EI}): \mathrm{m} / \mathrm{z}(\%)$ $=390\left[\mathrm{M}^{+}\right], 343,333,241,201,189,173,145,133,109,89,75$ (100), 73. HRMS: $m / z$ calcd. for $\mathrm{C}_{20} \mathrm{H}_{46} \mathrm{O}_{3} \mathrm{Si}_{2}: 390.2986$, found 390.2968 .

(1S,2R,3R)-3-(tert-Butyldimethylsilyloxy)-2-methyl-1-(2-oxoethyl)pentyl 2-Bromopropanoate (16a): 2-Bromopropionic acid (313 $\mu \mathrm{L}$, $3.48 \mathrm{mmol}$ ) and DMAP (114 $\mathrm{mg}, 0.93 \mathrm{mmol})$ was added to a solution of $15 \mathrm{a}(453 \mathrm{mg}, 1.16 \mathrm{mmol})$ in $\mathrm{CH}_{2} \mathrm{Cl}_{2}(5 \mathrm{~mL})$ at room temperature. After the solution was cooled to $0{ }^{\circ} \mathrm{C}, N, N$-dicyclohexylcarbodiimide (264 mg, $1.28 \mathrm{mmol}$ ) was added. The resulting solution was stirred for $5 \mathrm{~min}$ at $0{ }^{\circ} \mathrm{C}$ before it was warmed to room temperature. After additional stirring for $30 \mathrm{~min}$ at room temperature, the precipitate was filtered. The filtrate was concentrated and purified by flash chromatography (hexane/EtOAc, 10:1). The desired bromo ester was obtained as a colorless liquid (582 mg, 96\%). IR (film): $\tilde{v}=2928,2857,1738,1471,1381,1256 \mathrm{~cm}^{-1} .{ }^{1} \mathrm{H}$ NMR $\left(300 \mathrm{MHz}, \mathrm{CDCl}_{3}\right): \delta=5.12[\mathrm{~m}, 1 \mathrm{H}, \mathrm{CHO}(\mathrm{C}=\mathrm{O})], 4.32[\mathrm{q}, J=$ $7.0 \mathrm{~Hz}, 1 \mathrm{H},-\mathrm{C}(\mathrm{O}) \mathrm{CH}$ ], $3.60\left(\mathrm{~m}, 3 \mathrm{H}, \mathrm{CH}_{2} \mathrm{OSi}, \mathrm{CHOSi}\right), 1.89$ [m, $\left.3 \mathrm{H}, \mathrm{CH}_{2} \mathrm{CH}_{2} \mathrm{CH}(\mathrm{O}), \mathrm{CHCH}\left(\mathrm{CH}_{3}\right) \mathrm{CH}\right], 1.78(\mathrm{~d}, J=6.9 \mathrm{~Hz}, 3 \mathrm{H}$, $\left.\mathrm{BrCHCH} H_{3}\right), 1.5\left(\mathrm{~m}, 2 \mathrm{H}, \mathrm{CH}_{2} \mathrm{CH}_{3}\right), 0.90\left(\mathrm{~m}, 6 \mathrm{H}, \mathrm{CHCH}_{3}\right.$, $\left.\mathrm{CH}_{2} \mathrm{CH}_{3}\right), 0.86\left[\mathrm{~s}, 18 \mathrm{H}, \mathrm{SiC}\left(\mathrm{CH}_{3}\right)_{3}, \mathrm{SiC}\left(\mathrm{CH}_{3}\right)_{3}\right], 0.02(\mathrm{~s}, 6 \mathrm{H}$, $\left.2 \times \mathrm{SiCH}_{3}\right), 0.00\left(\mathrm{~s}, 6 \mathrm{H}, 2 \times \mathrm{SiCH}_{3}\right) \mathrm{ppm} .{ }^{13} \mathrm{C} \mathrm{NMR}(75 \mathrm{MHz}$, $\left.\mathrm{CDCl}_{3}\right): \delta=170.5,75.2,75.1,60.6,41.9,41.5,36.9,27.8,27.0$, $22.8,19.3,11.3,10.4,-2.94,-3.38,-4.33 \mathrm{ppm} .[\alpha]_{\mathrm{D}}^{24.5}=+5.9(c=$ 1.21, $\left.\mathrm{CHCl}_{3}\right)$. MS (EI): $m / z(\%)=524\left[\mathrm{M}^{+}\right], 526,343,290,241,211$, 173, 121 (100), 109, 89, 73. HRMS: $m / z$ calcd. for $\mathrm{C}_{23} \mathrm{H}_{49} \mathrm{BrO}_{4} \mathrm{Si}_{2}$ : 524.2353 , found 524.2335 .

The bromo ester $(582 \mathrm{mg}, 1.11 \mathrm{mmol})$ obtained as described above was dissolved in $\mathrm{MeOH}(3 \mathrm{~mL})$. To this solution DL-10-camphorsulfonic acid (51 $\mathrm{mg}, 0.22 \mathrm{mmol})$ was added. The resulting solution was stirred at $0{ }^{\circ} \mathrm{C}$ for $1 \mathrm{~h}$. The reaction was terminated by addition of $\mathrm{Et}_{3} \mathrm{~N}(162 \mu \mathrm{L}, 1.17 \mathrm{mmol})$. After the solution was concentrated, purification of the residue by flash chromatography (hexane/EtOAc, 3:1) gave the desired primary alcohol (285 mg, $63 \%$ ) as a colorless liquid. IR (film): $\tilde{v}=3425,2932,2856,1737$, $1471,1380,1257 \mathrm{~cm}^{-1} .{ }^{1} \mathrm{H}$ NMR $\left(300 \mathrm{MHz}, \mathrm{CDCl}_{3}\right): \delta=5.20[\mathrm{~m}$, $1 \mathrm{H}, \mathrm{CHO}(\mathrm{C}=\mathrm{O})], 4.38$ [q, $J=6.9 \mathrm{~Hz}, 1 \mathrm{H}, \mathrm{C}(=\mathrm{O}) \mathrm{CHBr}], 3.60(\mathrm{~m}$, $\left.3 \mathrm{H}, \mathrm{CH}_{2} \mathrm{OH}, \mathrm{CHOSi}\right), 2.23\left(\mathrm{~s}, 1 \mathrm{H}, \mathrm{CH}_{2} \mathrm{OH}\right), 1.92(\mathrm{~m}, 1 \mathrm{H}$, $\left.\mathrm{CHCH}_{3}\right), 1.86\left(\mathrm{~d}, J=6.9 \mathrm{~Hz}, 3 \mathrm{H}, \mathrm{BrCHCH}_{3}\right) 1.46(\mathrm{dq}, J=7.7$, $\left.5.9 \mathrm{~Hz}, 2 \mathrm{H}, \mathrm{CH}_{2} \mathrm{CH}_{3}\right), 0.96\left(\mathrm{~d}, J=6.9 \mathrm{~Hz}, 3 \mathrm{H}, \mathrm{CHCH}_{3}\right), 0.89[\mathrm{~s}$, $\left.9 \mathrm{H}, \mathrm{SiC}\left(\mathrm{CH}_{3}\right)_{3}\right], 0.84\left(\mathrm{t}, J=7.5 \mathrm{~Hz}, 3 \mathrm{H}, \mathrm{CH}_{2} \mathrm{CH}_{3}\right), 0.05(\mathrm{~s}, 3 \mathrm{H}$, $\left.\mathrm{SiCH}_{3}\right), 0.04$ (s, $\left.3 \mathrm{H}, \mathrm{SiCH}_{3}\right) \mathrm{ppm} .{ }^{13} \mathrm{C} \mathrm{NMR}\left(75 \mathrm{MHz} \mathrm{CDCl}_{3}\right): \delta$ $=171.6,74.9,74.4,59.2,41.9,40.9,36.6,27.2,26.6,22.4,18.8$, $11.0,10.2,-3.40,-3.78 \mathrm{ppm} .[\alpha]_{\mathrm{D}}^{23.9}=+4.4\left(c=1.43, \mathrm{CHCl}_{3}\right)$. MS (EI): $m / z(\%)=410\left[\mathrm{M}^{+}\right], 351,267,229,201,173(100), 153,127$, 109, 73, 55. HRMS: $\mathrm{m} / z$ calcd. for $\mathrm{C}_{17} \mathrm{H}_{35} \mathrm{BrO}_{4} \mathrm{Si}: 410.1488$, found 410.1486 .

The alcohol (285 mg, $0.69 \mathrm{mmol})$ obtained as describe above was dissolved in $\mathrm{CH}_{2} \mathrm{Cl}_{2}(5 \mathrm{~mL})$. To this solution was added Dess-Martin periodinane (DMP) $(352 \mathrm{mg}, 0.83 \mathrm{mmol})$. The resulting solution was stirred for $30 \mathrm{~min}$ at room temperature. After the reaction was completed, aqueous saturated $\mathrm{NaHCO}_{3}(10 \mathrm{~mL})$ was added and the mixture was extracted with $\mathrm{CH}_{2} \mathrm{Cl}_{2}(3 \times 10 \mathrm{~mL})$. The organic layer was separated, dried $\left(\mathrm{MgSO}_{4}\right)$, and concentrated. Purification of the residue by flash chromatography (hexane/EtOAc, 
7:1) offered the desired aldehyde 16a (204 mg, 72\%) as a yellow liquid. ${ }^{1} \mathrm{H}$ NMR $\left(300 \mathrm{MHz}, \mathrm{CDCl}_{3}\right): \delta=9.67[\mathrm{~s}, 1 \mathrm{H}, \mathrm{C}(\mathrm{O}) H], 5.40$ [dt, $J=6.9,4.2 \mathrm{~Hz}, 1 \mathrm{H}, \mathrm{CHO}(\mathrm{C}=\mathrm{O})], 4.27[\mathrm{q}, J=6.8 \mathrm{~Hz}, 1 \mathrm{H}$, $\mathrm{C}(=\mathrm{O}) \mathrm{CHBr}$ ], $3.56(\mathrm{~m}, 1 \mathrm{H}, \mathrm{CHOSi}), 2.79$ [dd, $J=16.6,4.0 \mathrm{~Hz}, 1$ $\mathrm{H}$, one of $\mathrm{CH}_{2} \mathrm{C}(=\mathrm{O}) \mathrm{H}$ ], 2.66 (ddd, $J=20.7,16.6,3.0 \mathrm{~Hz}, 1 \mathrm{H}$, $\left.\mathrm{BrCHCH}_{3}\right), 1.86\left(\mathrm{~m}, 1 \mathrm{H}, \mathrm{CHCH}_{3}\right), 1.74(\mathrm{~d}, J=6.9 \mathrm{~Hz}, 3 \mathrm{H}$, $\left.\mathrm{BrCHCH}_{3}\right), 1.47\left(\mathrm{dq}, J=13.7,6.3 \mathrm{~Hz}, 2 \mathrm{H}, \mathrm{CH}_{2} \mathrm{CH}_{3}\right), 0.90(\mathrm{~d}, J$ $\left.=7.8 \mathrm{~Hz}, 3 \mathrm{H}, \mathrm{CHCH}_{3}\right), 0.84\left[\mathrm{~s}, 9 \mathrm{H}, \mathrm{SiC}\left(\mathrm{CH}_{3}\right)_{3}\right], 0.80(\mathrm{t}, J=$ $\left.7.4 \mathrm{~Hz}, 3 \mathrm{H}, \mathrm{CH}_{2} \mathrm{CH}_{3}\right), 0.05$ (s, $\left.3 \mathrm{H}, \mathrm{SiCH}_{3}\right), 0.03$ (s, $3 \mathrm{H}, \mathrm{SiCH}_{3}$ ) ppm. ${ }^{13} \mathrm{C}$ NMR $\left(75 \mathrm{MHz}, \mathrm{CDCl}_{3}\right): \delta=200.1,170.3,74.9,72.4$, $47.5,41.3,40.4,27.2,26.6,22.2,18.8,11.1,10.5,-3.30,-3.71 \mathrm{ppm}$.

(6S)-6-[(1R,2R)-2-(tert-Butyldimethylsilyloxy)-1-methylbutyl]-4hydroxy-3-methyltetrahydro-2H-pyran-2-one (17a): Diiodomethane $(79 \mu \mathrm{L}, 0.98 \mathrm{mmol}$ ) was added to a mixture of samarium (powder, $162 \mathrm{mg}, 1.07 \mathrm{mmol})$ in THF $(5 \mathrm{~mL})$ at room temperature under nitrogen. Samarium(II) iodide was obtained as a blue-colored solution which was used after stirring for $2 \mathrm{~h}$. After the solution was cooled to $-78^{\circ} \mathrm{C}$, a solution of aldehyde 16 a $(200 \mathrm{mg}, 0.49 \mathrm{mmol})$ in THF $(1 \mathrm{~mL})$ was added under nitrogen. After being stirred for $1 \mathrm{~h}$ at $-78^{\circ} \mathrm{C}$, the solution was warmed to room temperature and $0.1 \mathrm{M} \mathrm{HCl}(8 \mathrm{~mL})$ was added. The mixture was extracted with diethyl ether $(3 \times 20 \mathrm{~mL})$. After the organic layer was washed with saturated sodium thiosulfate solution $(15 \mathrm{~mL})$ and sodium chloride solution $(15 \mathrm{~mL})$, the ethereal solution was dried $\left(\mathrm{MgSO}_{4}\right)$ and concentrated. Purification of the residue by flash chromatography (hexane/EtOAc, 3:1) provided the desired lactone 17a as a yellow liquid [92 $\mathrm{mg}(57 \%)$ and $3.9 \mathrm{mg}(2.4 \%)$, selectivity $24: 1] ; R_{\mathrm{f}}=0.57$ and 0.50 (hexane/EtOAc, 1:1), respectively. Spectroscopic data for the major isomer is as follows. IR (film): $\tilde{v}=3442,2933,2856$, 1713, 1462, 1380, 1258, $1197 \mathrm{~cm}^{-1} .{ }^{1} \mathrm{H}$ NMR (300 MHz, $\left.\mathrm{CDCl}_{3}\right)$ : $\delta=4.79[\mathrm{~m}, 1 \mathrm{H}, \mathrm{CHO}(\mathrm{C}=\mathrm{O})], 4.14(\mathrm{~s}, 1 \mathrm{H}, \mathrm{CHOH}), 3.61(\mathrm{~m}, 1$ $\mathrm{H}, \mathrm{CHOSi}), 2.44$ [qd, $J=7.2,3.2 \mathrm{~Hz}, 1 \mathrm{H}, \mathrm{C}(=\mathrm{O}) \mathrm{CHCH}_{3}$ ], 2.04 $\left(\mathrm{m}, 1 \mathrm{H}, \mathrm{CHCH}_{3}\right), 1.82\left(\mathrm{~m}, 2 \mathrm{H}, \mathrm{CH} \mathrm{H}_{2} \mathrm{CHOH}\right), 1.67(\mathrm{~m}, 2 \mathrm{H}$, $\left.\mathrm{CH}_{2} \mathrm{CH}_{3}\right), 1.28\left(\mathrm{~d}, J=7.2 \mathrm{~Hz}, 3 \mathrm{H}, \mathrm{CHCH}_{3}\right), 0.96(\mathrm{~d}, J=6.9 \mathrm{~Hz}$, $\left.3 \mathrm{H}, \mathrm{CHCH}_{3}\right), 0.83\left[\mathrm{~m}, 12 \mathrm{H}, \mathrm{CH}_{2} \mathrm{CH}_{3}, \mathrm{Si}\left(\mathrm{CH}_{3}\right)_{3}\right], 0.00$ (s, $6 \mathrm{H}$, $\mathrm{SiCH}_{3}$ ) ppm. ${ }^{13} \mathrm{C} \mathrm{NMR}\left(75 \mathrm{MHz}, \mathrm{CDCl}_{3}\right): \delta=174.9,75.1,68.5$, $42.5,37.1,27.1,26.6,18.8,11.7,10.9,10.3,-3.3,-3.8$ ppm. MS (EI): $m / z(\%)=330\left[\mathrm{M}^{+}\right], 301,215,197,173,73$ (100), 57. HRMS: $\mathrm{m} / z$ calcd. for $\mathrm{C}_{17} \mathrm{H}_{34} \mathrm{O}_{4} \mathrm{Si}: 330.2226$, found 330.2229 .

(6S)-4-Hydroxy-6-I(1S,2R)-2-hydroxy-1-methylbutyl]-3-methyl-5,6dihydro-2H-pyran-2-one (2a): Lactone 17 a $(50 \mathrm{mg}, 0.15 \mathrm{mmol})$ (a 24:1 mixture of diastereomers) obtained as described above was dissolved in $\mathrm{CH}_{2} \mathrm{Cl}_{2}(1 \mathrm{~mL})$. To this solution was added Dess-Martin periodinane (DMP) $(127 \mathrm{mg}, 0.30 \mathrm{mmol})$ and the resulting solution was stirred for $30 \mathrm{~min}$ at room temperature. After the reaction was completed, aqueous saturated $\mathrm{NaHCO}_{3}(5 \mathrm{~mL})$ was added and the mixture was extracted with $\mathrm{CH}_{2} \mathrm{Cl}_{2}(3 \times 10 \mathrm{~mL})$. The organic layer was separated, dried $\left(\mathrm{MgSO}_{4}\right)$, and concentrated. Purification of the residue by flash chromatography (hexane/EtOAc, 3:1) offered the desired ketone $\left(34 \mathrm{mg}, 68 \%\right.$ ) as a colorless liquid. ${ }^{1} \mathrm{H}$ $\operatorname{NMR}\left(300 \mathrm{MHz}, \mathrm{CDCl}_{3}\right): \delta=4.76$ [ddd, $J=11.8,6.1,2.8 \mathrm{~Hz}, 1$ $\mathrm{H}, \mathrm{CHO}(\mathrm{C}=\mathrm{O})], 3.59$ [dt, $J=6.4,3.5 \mathrm{~Hz}, 1 \mathrm{H}, \mathrm{C}(=\mathrm{O}) \mathrm{CHCH}_{3}$, $3.54\left[\mathrm{q}, J=6.6 \mathrm{~Hz}, 1 \mathrm{H}, \mathrm{C}(=\mathrm{O}) \mathrm{CHCH}_{3}\right], 2.73[\mathrm{dd}, J=19.0,2.9 \mathrm{~Hz}$, $1 \mathrm{H}$, one of $\left.\mathrm{CH}_{2} \mathrm{C}(=\mathrm{O})\right], 2.49[\mathrm{dd}, J=19.0,11.8 \mathrm{~Hz}, 1 \mathrm{H}$, one of $\left.\mathrm{CH}_{2} \mathrm{C}(=\mathrm{O})\right], 1.83\left(\mathrm{~m}, 1 \mathrm{H}, \mathrm{CHCHCH}_{3}\right), 1.36-1.61(\mathrm{~m}, 2 \mathrm{H}$, $\left.\mathrm{CH}_{2} \mathrm{CH}_{3}\right), 1.32\left[\mathrm{~d}, J=6.6 \mathrm{~Hz}, 3 \mathrm{H}, \mathrm{C}(=\mathrm{O}) \mathrm{CHCH}_{3}\right.$ ], 1.04 (d, $J=$ $\left.6.9 \mathrm{~Hz}, 3 \mathrm{H}, \mathrm{CH}_{2} \mathrm{CH}_{3}\right), 0.87\left[\mathrm{~m}, 12 \mathrm{H}, \mathrm{SiC}\left(\mathrm{CH}_{3}\right)_{3}, \mathrm{CH}_{2} \mathrm{CH}_{3}\right], 0.04$ $\left(\mathrm{s}, 3 \mathrm{H}, \mathrm{SiCH}_{3}\right), 0.00$ (s, $\left.3 \mathrm{H}, \mathrm{SiCH}_{3}\right) \mathrm{ppm} .{ }^{13} \mathrm{C}$ NMR $(75 \mathrm{MHz}$, $\left.\mathrm{CDCl}_{3}\right): \delta=202.7,170.7,75.8,75.2,52.3,42.5,42.2,26.9,26.5$, $18.8,11.1,10.9,8.42,-3.30,-3.80 \mathrm{ppm}$.

The lactone (29 $\mathrm{mg}, 0.09 \mathrm{mmol}$ ) prepared as described above was

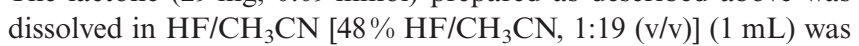

stirred for $1 \mathrm{~h}$ at room temperature. The reaction was terminated by addition of solid $\mathrm{CaCO}_{3}(30 \mathrm{mg})$. After the mixture was filtered with aid of Celite and washed with diethyl ether $(3 \times 10 \mathrm{~mL})$ and the filtrate was concentrated. Purification of the residue by flash chromatography (hexane/EtOAc, 1:1 to $1: 2$ ) provided the desired lactone 2a (14 mg, $74 \%)$ as a white solid: M.p. $108-110^{\circ} \mathrm{C}$. IR (film): $\tilde{v}=3427,2970,1724,1255 \mathrm{~cm}^{-1} \cdot{ }^{1} \mathrm{H}$ NMR $(500 \mathrm{MHz}$, $\mathrm{MeOH}): \delta=4.24$ [ddd, $J=12.3,6.4,3.8 \mathrm{~Hz}, 1 \mathrm{H}, \mathrm{CHOC}(=\mathrm{O})$ ], $3.53(\mathrm{dt}, J=6.6,3.4 \mathrm{~Hz}, 1 \mathrm{H}, \mathrm{CHOH}), 2.59-2.65(\mathrm{~m}, 1 \mathrm{H}$, one of $\left.\mathrm{CH}_{2} \mathrm{COH}\right), 2.38\left(\mathrm{dd}, J=16.9,3.3 \mathrm{~Hz}, 1 \mathrm{H}\right.$, one of $\left.\mathrm{CH}_{2} \mathrm{COH}\right), 1.69$ (quintet of d, $\left.J=6.8,3.4 \mathrm{~Hz}, 1 \mathrm{H}, \mathrm{CHCH}_{3}\right), 1.63(\mathrm{~s}, 3 \mathrm{H}$, $-\mathrm{C}=\mathrm{CCH}_{3}$ ), 1.43 (quintet, $\left.J=7.2 \mathrm{~Hz}, 2 \mathrm{H}, \mathrm{CH}_{2} \mathrm{CH}_{3}\right), 0.95(\mathrm{~d}, J=$ $\left.6.9 \mathrm{~Hz}, 3 \mathrm{H}, \mathrm{CHCH}_{3}\right), 0.87$ (t, $J=7.4 \mathrm{~Hz}, 3 \mathrm{H}, \mathrm{CH}_{2} \mathrm{CH}_{3}$ ) ppm. ${ }^{13} \mathrm{C}$ NMR $(75 \mathrm{MHz}, \mathrm{MeOH}): \delta=173,169,99.2,79.1,73.9,43.3$, $32.6,28.9,11.4,9.78,8.95$ ppm. $[\alpha]_{\mathrm{D}}^{26.5}=13.53(c=0.82, \mathrm{MeOH})$. MS (EI): $m / z(\%)=214\left[\mathrm{M}^{+}\right], 167,157,141,129,116,111,101$, 83, 71, 55 (100). HRMS: $m / z$ calcd. for $\mathrm{C}_{11} \mathrm{H}_{18} \mathrm{O}_{4}$ : 214.1205, found 214.1205 .

(6R)-4-Hydroxy-6-[(1S,2R)-2-hydroxy-1-methylbutyl]-3-methyl-5,6dihydro-2 $\boldsymbol{H}$-pyran-2-one (2b): Lactone $\mathbf{1 7 b}(83 \mathrm{mg}, 0.25 \mathrm{mmol}$ ) (a 20:1 mixture of diastereomers) obtained above was dissolved in $\mathrm{CH}_{2} \mathrm{Cl}_{2}(2 \mathrm{~mL})$. To this solution was added Dess-Martin reagent $(213 \mathrm{mg}, 0.50 \mathrm{mmol})$ and the resulting solution was stirred for $30 \mathrm{~min}$ at room temperature. After the reaction was completed, aqueous saturated $\mathrm{NaHCO}_{3}(5 \mathrm{~mL})$ was added and mixture was extracted with $\mathrm{CH}_{2} \mathrm{Cl}_{2}(3 \times 10 \mathrm{~mL})$. The organic layer was separated, dried $\left(\mathrm{MgSO}_{4}\right)$, and concentrated. Purification of the residue by flash chromatography (hexane/EtOAc, 3:1) offered the desired ketone $(56 \mathrm{mg}, 68 \%)$ as a colorless liquid. ${ }^{1} \mathrm{H}$ NMR $(300 \mathrm{MHz}$, $\mathrm{CDCl}_{3}$ ): $\delta=7.99$ (br., $1 \mathrm{H}, \mathrm{C}-\mathrm{OH}$ ), 4.22 [dd, $J=16.8,8.7 \mathrm{~Hz}, 1$ $\mathrm{H}, \mathrm{CHOC}(=\mathrm{O})], 4.04$ (ddd, $J=9.7,6.0,1.6 \mathrm{~Hz}, 1 \mathrm{H}, \mathrm{CHOSi}), 2.50$ (d, $\left.J=7.6 \mathrm{~Hz}, 2 \mathrm{H}, \mathrm{CH}_{2} \mathrm{C}-\mathrm{OH}\right), 1.84\left(\mathrm{~m}, 1 \mathrm{H}, \mathrm{CHCH}_{3}\right), 1.79$ (s, 3 $\left.\mathrm{H}, \mathrm{C}=\mathrm{CCH}_{3}\right), 1.49\left(\mathrm{~m}, 2 \mathrm{H}, \mathrm{CH}_{2} \mathrm{CH}_{3}\right), 0.84\left[\mathrm{~m}, 15 \mathrm{H}, \mathrm{CHCH}_{3}\right.$, $\left.\mathrm{CH}_{2} \mathrm{CH}_{3}, \mathrm{SiC}\left(\mathrm{CH}_{3}\right)_{3}\right], 0.04\left(\mathrm{~s}, 3 \mathrm{H}, \mathrm{SiCH}_{3}\right), 0.00\left(\mathrm{~s}, 3 \mathrm{H}, \mathrm{SiCH}_{3}\right)$ ppm. ${ }^{13} \mathrm{C} \mathrm{NMR}\left(75 \mathrm{MHz}, \mathrm{CDCl}_{3}\right): \delta=202.5,75.6,71.5,52.3,42.4$, $41.1,32.4,28.3,26.5,18.7,10.7,8.97,8.46,8.23,-3.55,-4.04$ ppm.

The lactone $(45 \mathrm{mg}, 0.14 \mathrm{mmol}$ ) prepared as described above was dissolved in $\mathrm{HF} / \mathrm{CH}_{3} \mathrm{CN}\left[48 \% \mathrm{HF} / \mathrm{CH}_{3} \mathrm{CN}, 1: 19(\mathrm{v} / \mathrm{v})\right](1 \mathrm{~mL})$ and the resulting solution was stirred for $1 \mathrm{~h}$ at room temperature. The reaction was terminated by addition of solid $\mathrm{CaCO}_{3}(30 \mathrm{mg})$ After the mixture was filtered with diethyl ether $(3 \times 10 \mathrm{~mL})$ and concentrated. Purification by flash chromatography (hexane/EtOAc, 1:1 to $1: 2)$ provided the desired lactone $\mathbf{2 b}(20.5 \mathrm{mg}, 70 \%)$ as a white solid. m.p. $106-107^{\circ} \mathrm{C}$. IR (film): $\tilde{v}=3431,2931,1728,1255$, $1138 \mathrm{~cm}^{-1} .{ }^{1} \mathrm{H}$ NMR $(300 \mathrm{MHz}, \mathrm{MeOH}): \delta=4.24$ [ddd, $J=11.6$, $8.5,4.8 \mathrm{~Hz}, 1 \mathrm{H}, \mathrm{CHOC}(=\mathrm{O})], 3.80(\mathrm{ddd}, J=11.6,5.1,2.0 \mathrm{~Hz}, 1$ $\mathrm{H}, \mathrm{CHOH}), 2.49\left(\mathrm{dd}, J=11.7,1.7 \mathrm{~Hz}, 1 \mathrm{H}\right.$, one of $\left.\mathrm{CH}_{2} \mathrm{C}-\mathrm{OH}\right)$, $2.34-2.52\left(\mathrm{~m}, 1 \mathrm{H}, \mathrm{CH} \mathrm{H}_{2} \mathrm{C}-\mathrm{OH}\right), 1.72\left(\mathrm{~m}, 1 \mathrm{H}, \mathrm{CHCH}_{3}\right), 1.62(\mathrm{~s}, 3$ $\left.\mathrm{H},-\mathrm{C}=\mathrm{CCH}_{3}\right), 1.28-1.52\left(\mathrm{~m}, 2 \mathrm{H}, \mathrm{CH}_{2} \mathrm{CH}_{3}\right), 0.87(\mathrm{t}, J=7.4 \mathrm{~Hz}$, $3 \mathrm{H}, \mathrm{CH}_{2} \mathrm{CH}_{3}$ ), 0.79 (d, $\left.J=7.0 \mathrm{~Hz}, 3 \mathrm{H}, \mathrm{CHCH}_{3}\right) \mathrm{ppm} .{ }^{13} \mathrm{C} \mathrm{NMR}$ (75 MHz, MeOH): $\delta=172.8,168.8,99.4,78.2,72.4,43.4,32.8$, $29.1,11.5,8.9,8.6$ ppm. $[\alpha]_{\mathrm{D}}^{23.8}=4.17(c=0.42 \mathrm{MeOH})$. MS (EI): $\mathrm{m} / \mathrm{z}(\%)=214\left[\mathrm{M}^{+}\right], 179,167,156,141,127,121,111,101(100)$, 95, 83, 71, 55. HRMS: $m / z$ calcd. for $\mathrm{C}_{11} \mathrm{H}_{18} \mathrm{O}_{4}$ : 214.1205, found 214.1206

$\left.\left(4 R, 3^{\prime} S, 4^{\prime} R, 5^{\prime} R\right)-4-B e n z y\right]-3-\left[5^{\prime}\right.$-[(4-methoxybenzyl)oxy]-3' hydroxy $-4^{\prime}$ - methylheptanoyl]-2-oxazolidinone (18a) and $\left(4 R, 3^{\prime} R, 4^{\prime} R, 5^{\prime} R\right)-4-B e n z y l-3-\left[5^{\prime}-\right.$ - (4-methoxybenzyl)oxy]-3' -hydroxy-4'-methylheptanoyl]-2-oxazolidinone (18b): Diiodomethane $(256 \mu \mathrm{L}, 3.17 \mathrm{mmol}$ ) was added to a mixture of samarium (powder, $573 \mathrm{mg}, 3.81 \mathrm{mmol})$ in THF $(5 \mathrm{~mL})$ at room temperature under nitrogen. Samarium(II) iodide was obtained as a greenish blue 
solution which was used after stirring for $2 \mathrm{~h}$. After the solution was cooled to $-78^{\circ} \mathrm{C}$, a solution of aldehyde $\mathbf{1 3 b}(300 \mathrm{mg}$, $1.27 \mathrm{mmol})$ and oxazolidinone $\mathbf{6 b}(379 \mathrm{mg}, 1.27 \mathrm{mmol})$ in THF $(5 \mathrm{~mL})$ was added under nitrogen. After it was stirred for $1 \mathrm{~h}$ at $-78^{\circ} \mathrm{C}$, the solution was warmed to room temperature and $0.1 \mathrm{M}$ $\mathrm{HCl}(10 \mathrm{~mL})$ was added. The mixture was extracted with diethyl ether $(3 \times 15 \mathrm{~mL})$. After the organic layer was washed with saturated sodium thiosulfate solution $(20 \mathrm{~mL})$ and sodium chloride solution $(20 \mathrm{~mL})$, the ethereal solution was dried $\left(\mathrm{MgSO}_{4}\right)$ and concentrated. Purification of the residue by flash chromatography (hexane/EtOAc, 3:1) provided the desired 18a and $\mathbf{1 8 b}$ as yellow liquids $344 \mathrm{mg}(60 \%)$ and $26 \mathrm{mg}(4.5 \%)$ (selectivity 13:1) [minor compound 18b: $R_{\mathrm{f}}=0.38$ and major compound 18a: $R_{\mathrm{f}}=0.31$. (hexane/EtOAc, 2:1)].

18a: IR (film): $\tilde{v}=3453,3058,2930,1781,1700,1613,1514,1455$, $1390 \mathrm{~cm}^{-1} .{ }^{1} \mathrm{H}$ NMR $\left(300 \mathrm{MHz}, \mathrm{CDCl}_{3}\right): \delta=7.27-7.12(\mathrm{~m}, 7 \mathrm{H}$, $\left.P h \mathrm{CH}_{2} \mathrm{CHN}-,-\mathrm{OCH}_{2} \mathrm{ArOCH}{ }_{3}\right), 6.78\left(\mathrm{~d}, \mathrm{~J}=8.6 \mathrm{~Hz}, 2 \mathrm{H}, \mathrm{OCH}_{2}-\right.$ $\left.A r \mathrm{OCH}_{3}\right), 4.62$ (ddt, $J=10.4,7.0,3.3 \mathrm{~Hz}, 1 \mathrm{H}, \mathrm{PhCH}_{2} \mathrm{CHN}-$ ), $4.46\left(\mathrm{dd}, J=17.6,10.4 \mathrm{~Hz}, 2 \mathrm{H},-\mathrm{OCH}_{2} \mathrm{ArOCH}_{3}\right), 4.10(\mathrm{~m}, 3 \mathrm{H}$, $\left.-\mathrm{CHOH}, \mathrm{PhCH}_{2} \mathrm{CHCH}_{2} \mathrm{O}-\right), 3.80\left(\mathrm{~d}, J=3.6 \mathrm{~Hz}, 1 \mathrm{H},-\mathrm{CHOCH}_{2-}\right.$ $\left.\mathrm{ArOCH}_{3}\right), 3.70\left(\mathrm{~s}, 3 \mathrm{H},-\mathrm{OCH}_{2} \mathrm{ArOCH}_{3}\right), 3.52(\mathrm{~m}, 1 \mathrm{H},-\mathrm{CHOH})$, 3.21 (dd, $J=13.4,3.2 \mathrm{~Hz}, 1 \mathrm{H}, \mathrm{PhCH}_{2} \mathrm{CHCH}_{2} \mathrm{O}-$ ), 3.04 (dd, $J=$ 6.2, $\left.3.5 \mathrm{~Hz}, 2 \mathrm{H},-\mathrm{COCH}_{2} \mathrm{CH}\right), 2.69(\mathrm{dd}, J=13.4,9.6 \mathrm{~Hz}, 1 \mathrm{H}$, $\mathrm{PhCH}_{2} \mathrm{CHCH}_{2} \mathrm{O}-$ ), 1.84 (quintet of d, $J=7.1,2.6 \mathrm{~Hz}, 1 \mathrm{H}$, $\left.\mathrm{OHCHCHCH}_{3}\right), 1.66\left(\mathrm{~m}, 1 \mathrm{H},-\mathrm{CH}_{2} \mathrm{CH}_{3}\right), 1.45(\mathrm{~m}, 1 \mathrm{H}$, $\left.-\mathrm{CH}_{2} \mathrm{CH}_{3}\right), 0.86\left(\mathrm{~m}, 6 \mathrm{H},-\mathrm{CH}_{2} \mathrm{CH}_{3},-\mathrm{CHCH}_{3}\right) \mathrm{ppm} .{ }^{13} \mathrm{C} \mathrm{NMR}$ $\left(100 \mathrm{MHz}, \mathrm{CDCl}_{3}\right): \delta=172.1,159.1,153.5,135.2,130.4,129.4$, $129.4,128.9,127.2,113.7,82.5,71.4,70.6,66.2,55.2,41.3,39.3$, $37.8,23.0,11.6,10.7$ ppm. $[\alpha]_{\mathrm{D}}^{28.0}=-76.5\left(c=1.92, \mathrm{CHCl}_{3}\right) . \mathrm{MS}$ (EI): $m / z(\%)=455\left[\mathrm{M}^{+}\right], 302,249,219,178,137,121(100), 86$, 69. HRMS: $m / z$ calcd. for $\mathrm{C}_{26} \mathrm{H}_{33} \mathrm{NO}_{6}$ : 455.2308, found 455.2308 .

18b: IR (film): $\tilde{v}=3459,3054,2926,2852,1782,1695,1612,1514$, 1457, $1384 \mathrm{~cm}^{-1} .{ }^{1} \mathrm{H}$ NMR $\left(300 \mathrm{MHz}, \mathrm{CDCl}_{3}\right): \delta=7.29-7.12(\mathrm{~m}$, $\left.7 \mathrm{H}, \mathrm{PhCH}_{2} \mathrm{CHN}-,-\mathrm{OCH}_{2} \mathrm{ArOCH}_{3}\right), 6.78(\mathrm{~d}, J=8.6 \mathrm{~Hz}, 2 \mathrm{H}$, $-\mathrm{OCH}_{2} \mathrm{ArOCH}_{3}$ ), $4.60(\mathrm{ddt}, J=10.6,6.8,3.2 \mathrm{~Hz}, 1 \mathrm{H}$, $\mathrm{PhCH}_{2} \mathrm{CHN}-$ ), 4.49 (d, $\left.J=11.1 \mathrm{~Hz}, 1 \mathrm{H},-\mathrm{OCH}_{2} \mathrm{ArOCH}_{3}\right) 4.31$ (d, $J=11.1 \mathrm{~Hz}, 1 \mathrm{H},-\mathrm{OCH}_{2} \mathrm{ArOCH}_{3}$ ), 4.21 (br. t, $J=4.3 \mathrm{~Hz}, 1$ $\mathrm{H},-\mathrm{CHOH}), 4.11\left(\mathrm{~m}, 2 \mathrm{H}, \mathrm{PhCH}_{2} \mathrm{CHCH}_{2} \mathrm{O}-\right.$ ), 3.71 (s, $3 \mathrm{H}$, $\left.-\mathrm{OCH}_{2} \mathrm{ArOCH}_{3}\right), 3.42\left(\mathrm{~m}, 1 \mathrm{H},-\mathrm{CHOCH}_{2} \mathrm{ArOCH}_{3}\right), 3.32$ (s, 1 $\mathrm{H},-\mathrm{CHOH}), 3.23\left(\mathrm{dd}, J=13.4,3.2 \mathrm{~Hz}, 1 \mathrm{H},-\mathrm{PhCH}_{2} \mathrm{CHCH}_{2}-\right.$ $\mathrm{O}-), 3.10\left(\mathrm{dd}, J=16.8,9.2 \mathrm{~Hz}, 1 \mathrm{H}, \mathrm{COCH}_{2} \mathrm{CH}\right), 2.84(\mathrm{dd}, J=$ 16.7, $\left.3.3 \mathrm{~Hz}, 1 \mathrm{H},-\mathrm{COCH}_{2} \mathrm{CH}\right), 2.68(\mathrm{dd}, J=13.4,9.6 \mathrm{~Hz}, 1 \mathrm{H}$, $\left.\mathrm{PhCH}_{2} \mathrm{CHCH}_{2} \mathrm{O}-\right), 1.73\left(\mathrm{~m}, 2 \mathrm{H},-\mathrm{OHCHCHCH},-\mathrm{CH}_{2} \mathrm{CH}_{3}\right)$, $\left.1.50\left(\mathrm{~m}, 1 \mathrm{H},-\mathrm{CH}_{2} \mathrm{CH}_{3}\right), 0.95(\mathrm{~d}, J=7.1 \mathrm{~Hz}, 3 \mathrm{H},-\mathrm{CH} \mathrm{CH})_{3}\right), 0.8$ (t, $\left.J=7.5 \mathrm{~Hz}, 3 \mathrm{H},-\mathrm{CH}_{2} \mathrm{CH}_{3}\right)$ ppm. ${ }^{13} \mathrm{C} \mathrm{NMR}\left(100 \mathrm{MHz}, \mathrm{CDCl}_{3}\right)$ : $\delta=172.4,159.1,153.4,135.2,130.6,129.4,128.9,127.3,113.8$, $83.5,70.7,70.6,66.2,55.2,55.1,41.0,39.1,37.7,23.1,10.0,7.4$ ppm. $[\alpha]_{\mathrm{D}}^{20.9}=-54.1\left(c=1.23, \mathrm{CHCl}_{3}\right)$. MS (EI): $\mathrm{m} / \mathrm{z}(\%)=455$ $\left[\mathrm{M}^{+}\right], 301,248,219,178,137,121(100), 86,77,65 . \mathrm{HRMS}: \mathrm{m} / \mathrm{z}$ calcd. for $\mathrm{C}_{26} \mathrm{H}_{33} \mathrm{NO}_{6}$ : 455.2308, found 455.2304.

(3S,4S,5R)-1,3-Bis(tert-butyldimethylsilyloxy)-4-methylheptan-5-ol (19a): 2,6-Lutidine $(19 \mu \mathrm{L}, 0.17 \mathrm{mmol})$ and TBSOTf $(38 \mu \mathrm{L}$, $0.17 \mathrm{mmol}$ ) was added to a solution of $\mathbf{1 8 a}(50.0 \mathrm{mg}, 0.11 \mathrm{mmol})$ in $\mathrm{CH}_{2} \mathrm{Cl}_{2}(5 \mathrm{~mL})$ at $0{ }^{\circ} \mathrm{C}$. The resulting solution was stirred at $0{ }^{\circ} \mathrm{C}$ for $1 \mathrm{~h}$. The reaction was terminated by addition of $\mathrm{NaHNO}_{3}$ $(5 \mathrm{~mL})$ and extracted with $\mathrm{CH}_{2} \mathrm{Cl}_{2}(3 \times 10 \mathrm{~mL})$. The organic layer was separated, dried $\left(\mathrm{MgSO}_{4}\right)$, and concentrated. Purification of the residue by flash chromatography (hexane/EtOAc, 7:1) offered the desired TBS-protected compound (51 mg, 82\%) as a colorless liquid. IR (film): $\tilde{v}=2958,1784,1699,1513,1462,1384,1248$, $1198 \mathrm{~cm}^{-1} .{ }^{1} \mathrm{H} \mathrm{NMR}\left(300 \mathrm{MHz}, \mathrm{CDCl}_{3}\right): \delta=7.20(\mathrm{~m}, 5 \mathrm{H}$, $P h \mathrm{CH}_{2} \mathrm{CHN}-$ ), 7.11 (d, $\left.J=7.9 \mathrm{~Hz}, 2 \mathrm{H},-\mathrm{OCH}_{2} \operatorname{ArOCH}_{3}\right), 6.78$ (d,
$\left.J=8.6 \mathrm{~Hz}, 2 \mathrm{H},-\mathrm{OCH}_{2} A r \mathrm{OCH}_{3}\right), 4.54\left(\mathrm{~m}, 1 \mathrm{H}, \mathrm{PhCH}_{2}\right.$ $\mathrm{C} H \mathrm{~N}-), 4.44\left(\mathrm{~d}, J=11.0 \mathrm{~Hz}, 1 \mathrm{H},-\mathrm{OCH}_{2} \mathrm{ArOCH}_{3}\right), 4.30(\mathrm{~m}, 2$ $\left.\mathrm{H},-\mathrm{OCH}_{2} \mathrm{ArOCH}_{3},-\mathrm{CH}_{2} \mathrm{CHOTBS}\right), 4.03(\mathrm{~d}, J=5.0 \mathrm{~Hz}, 2 \mathrm{H}$, $\left.\mathrm{PhCH}_{2} \mathrm{CHCH}_{2} \mathrm{O}-\right), 3.69$ (s, $\left.3 \mathrm{H},-\mathrm{OCH}_{2} \mathrm{ArOCH}_{3}\right), 3.43$ (dd, $J=$ $16.0,9.2 \mathrm{~Hz}, 1 \mathrm{H},-\mathrm{CHCHOCH} \mathrm{CH}_{2} \mathrm{Ar}, 3.18(\mathrm{~m}, 2 \mathrm{H}$, $\left.\mathrm{PhCH}_{2} \mathrm{CHCH}_{2} \mathrm{O}-\right), 2.67$ (dd, $\left.J=16.0,2.6 \mathrm{~Hz}, 1 \mathrm{H}, \mathrm{COCH}_{2} \mathrm{CH}\right)$, $2.56\left(\mathrm{dd}, J=13.3,9.9 \mathrm{~Hz}, 1 \mathrm{H}, \mathrm{COCH}_{2} \mathrm{CH}\right), 1.85(\mathrm{~m}, 1 \mathrm{H}$, TBSOCHCHCHO-), $1.56\left(\mathrm{~m}, 2 \mathrm{H},-\mathrm{CH}_{2} \mathrm{CH}_{3}\right), 0.95(\mathrm{~d}, J=6.1 \mathrm{~Hz}$, $\left.3 \mathrm{H},-\mathrm{CH} \mathrm{CH} \mathrm{CH}_{3}\right), 0.84\left[\mathrm{~m}, 12 \mathrm{H},-\mathrm{CHCH}_{3},-\mathrm{Si}\left(\mathrm{CH}_{3}\right)_{2} \mathrm{C}\left(\mathrm{CH}_{3}\right)_{3}\right]$, $-0.01\left[\mathrm{~d}, J=3.6 \mathrm{~Hz}, 6 \mathrm{H},-\mathrm{Si}\left(\mathrm{CH}_{3}\right)_{2} \mathrm{C}\left(\mathrm{CH}_{3}\right)_{3}\right] \mathrm{ppm} .{ }^{13} \mathrm{C} \mathrm{NMR}$ $\left(75 \mathrm{MHz}, \mathrm{CDCl}_{3}\right): \delta=172.1,158.9,153.3,135.4,131.0,129.4$, $129.0,128.9,127.3,113.7,81.7,71.2,71.1,65.9,55.3,55.2,42.1$, $38.4,37.8,25.7,25.6,23.8,9.5,9.0,-3.6,-4.6,-4.8 \mathrm{ppm} .[\alpha]_{\mathrm{D}}^{28.1}=$ $-62.44\left(c=1.27, \mathrm{CHCl}_{3}\right)$. MS (EI): $m / z(\%)=569\left[\mathrm{M}^{+}\right], 374,362$, 301, 276, 252, 241, 218, 185, 121 (100), 91, 73, 59. HRMS: $m / z$ calcd. for $\mathrm{C}_{32} \mathrm{H}_{47} \mathrm{NO}_{6} \mathrm{Si}$ : 569.3173, found 569.3171 .

To a solution of the TBS-protected compound ( $381 \mathrm{mg}, 0.65 \mathrm{mmol}$ ) as described above in diethyl ether $(10 \mathrm{~mL})$ was added distilled water $(21 \mu \mathrm{L}, 1.21 \mathrm{mmol})$. After the solution was cooled to $0{ }^{\circ} \mathrm{C}$, lithium borohydride $(810 \mu \mathrm{L}$ of a 2.0 m solution in THF, $1.62 \mathrm{mmol}$ ) was added slowly with stirring. After $10 \mathrm{~min}$, the temperature of the solution was raised to room temperature, and the resulting solution was stirred for additional $1 \mathrm{~h}$. The reaction was terminated with addition of aqueous $\mathrm{NaOH}$ solution $(1.0 \mathrm{M}$, $15 \mathrm{~mL})$ and extracted with diethyl ether $(3 \times 10 \mathrm{~mL})$. After the organic layer was washed with saturated sodium chloride solution $(15 \mathrm{~mL})$, the ethereal solution was dried $\left(\mathrm{MgSO}_{4}\right)$ and concentrated. Purification of the residue by flash chromatography (hexane/EtOAc, 7:1) provided the desired alcohol compound as a colorless liquid (250 mg, 94\%). IR (film): $\tilde{v}=3429,2955,1612,1514$, 1461, 1249, $1060 \mathrm{~cm}^{-1} .{ }^{1} \mathrm{H}$ NMR (300 MHz, $\left.\mathrm{CDCl}_{3}\right): \delta=7.15(\mathrm{~m}$. $2 \mathrm{H}, \operatorname{Ar} H), 6.77(\mathrm{~m}, 2 \mathrm{H}, \operatorname{Ar} H), 4.42(\mathrm{~d}, J=11.1 \mathrm{~Hz}, 1 \mathrm{H},-\mathrm{CO}-$ $\left.\mathrm{CH}_{2} \mathrm{Ar}\right), 4.26\left(\mathrm{~d}, J=11.1 \mathrm{~Hz}, 1 \mathrm{H},-\mathrm{COCH}_{2} \mathrm{Ar}\right), 3.76$ (q, $J=$ $\left.5.8 \mathrm{~Hz}, 1 \mathrm{H},-\mathrm{CH}_{2} \mathrm{CHCHCH}_{3}\right), 3.70\left(\mathrm{~s}, 3 \mathrm{H},-\mathrm{ArOCH}_{3}\right), 3.63-3.57$ $\left(\mathrm{m}, 2 \mathrm{H}, \mathrm{HOCH}_{2}-\right), 3.29\left(\mathrm{~m}, 1 \mathrm{H},-\mathrm{HCCHCH}_{2}\right), 1.91(\mathrm{~s}, 1 \mathrm{H}$, $-\mathrm{OH}), 1.72\left(\mathrm{~m}, 2 \mathrm{H}, \mathrm{OHCH}_{2} \mathrm{CH}_{2}-\right), 1.68-1.42(\mathrm{~m}, 3 \mathrm{H}$, $\left.-\mathrm{CH}_{2} \mathrm{CH}_{3},-\mathrm{CHCHCH}_{3}\right), 0.84\left(\mathrm{~d}, \mathrm{~J}=7.1 \mathrm{~Hz}, 3 \mathrm{H},-\mathrm{CHCHCH}_{3}\right)$, $0.81\left(\mathrm{t}, J=7.2 \mathrm{~Hz}, 3 \mathrm{H},-\mathrm{CH}_{2} \mathrm{CH}_{3}\right), 0.81\left[\mathrm{~s}, 9 \mathrm{H},-\mathrm{Si}\left(\mathrm{CH}_{3}\right)_{2} \mathrm{C}-\right.$ $\left.\left(\mathrm{CH}_{3}\right)_{3}\right], 0.00\left[\mathrm{~d}, J=9.5 \mathrm{~Hz}, 6 \mathrm{H}, \mathrm{Si}\left(\mathrm{CH}_{3}\right)_{2} \mathrm{C}\left(\mathrm{CH}_{3}\right)_{3}\right] \mathrm{ppm} .{ }^{13} \mathrm{C}$ NMR $\left(75 \mathrm{MHz}, \mathrm{CDCl}_{3}\right): \delta=159.7,131.9,129.9,114.4,80.6,73.6$, 71.7, 61.0, 56.0, 40.8, 36.3, 26.6, 24.7, 18.7, 11.3, 10.8, -3.7, -3.7 ppm. $[a]_{\mathrm{D}}^{23.4}=-23.5\left(c=1.75, \mathrm{CHCl}_{3}\right) . \mathrm{MS}(\mathrm{EI}): \mathrm{m} / \mathrm{z}(\%)=396$ $\left[\mathrm{M}^{+}\right], 260,201,189,145,137,122$ (100), 89, 75, 57. HRMS: $\mathrm{m} / \mathrm{z}$ calcd. for $\mathrm{C}_{22} \mathrm{H}_{40} \mathrm{O}_{4} \mathrm{Si}$ : 396.2696, found 396.2693.

The alcohol (250 mg, $0.63 \mathrm{mmol})$ obtained as described above was dissolved in DMF $(5 \mathrm{~mL})$. To this solution was added a solution of imidazole $(61 \mathrm{mg}, 0.90 \mathrm{mmol})$ and tert-butyldimethylsilyl chloride $(118 \mathrm{mg}, 0.78 \mathrm{mmol})$ in DMF $(2 \mathrm{~mL})$ at $0{ }^{\circ} \mathrm{C}$ under nitrogen. After it was stirred for $10 \mathrm{~min}$ at $0{ }^{\circ} \mathrm{C}$, the solution was warmed to room temperature and stirred for additional $2 \mathrm{~h}$ at room temperature. After the reaction was completed, aqueous saturated $\mathrm{NH}_{4} \mathrm{Cl}$ $(10 \mathrm{~mL})$ was added and the mixture was extracted with $\mathrm{CH}_{2} \mathrm{Cl}_{2}$ $(3 \times 20 \mathrm{~mL})$. The organic layer was separated, dried $\left(\mathrm{MgSO}_{4}\right)$, and concentrated. Purification of the residue by flash chromatography (hexane/EtOAc, 20:1) offered the desired compound (305 mg, 95\%) as a colorless oil. IR (film): $\tilde{v}=2954,1614,1587,1513,1462,1388$, $1360 \mathrm{~cm}^{-1} \cdot{ }^{1} \mathrm{H}$ NMR $\left(300 \mathrm{MHz}, \mathrm{CDCl}_{3}\right): \delta=7.30(\mathrm{~m}, 2 \mathrm{H}, \mathrm{Ar} H)$, $6.88(\mathrm{~m}, 2 \mathrm{H}, \mathrm{Ar} H), 4.53\left(\mathrm{~d}, J=10.9 \mathrm{~Hz}, 1 \mathrm{H},-\mathrm{COCH}_{2} \mathrm{Ar}\right), 4.26$ $\left(\mathrm{d}, J=10.9 \mathrm{~Hz}, 1 \mathrm{H},-\mathrm{COCH} \mathrm{H}_{2} \mathrm{Ar}\right), 3.90(\mathrm{~m}, 1 \mathrm{H}$, $\left.-\mathrm{CH}_{2} \mathrm{CHCHCH}_{3}\right), 3.81\left(\mathrm{~s}, 3 \mathrm{H},-\mathrm{ArOCH}_{3}\right), 3.66(\mathrm{~m}, 2 \mathrm{H}$, TBSOCH $\left.\mathrm{CH}_{2}-\right), 3.45$ (q, $\left.J=5.7 \mathrm{~Hz}, 1 \mathrm{H},-\mathrm{HCCHCH}_{2}-\right), 1.86-$ $1.60\left(\mathrm{~m}, 5 \mathrm{H},-\mathrm{CH}_{2} \mathrm{CH}_{3},-\mathrm{CHCHCH}_{3} \mathrm{TBSOCH}_{2} \mathrm{CH}_{2} \mathrm{CH}_{2}-\right), 0.98$ $\left(\mathrm{d}, J=6.9 \mathrm{~Hz}, 3 \mathrm{H},-\mathrm{CHCHCH}_{3}\right), 0.95(\mathrm{t}, J=7.3 \mathrm{~Hz}, 3 \mathrm{H}$, 
$\left.-\mathrm{CH}_{2} \mathrm{CH}_{3}\right), 0.94\left[\mathrm{~s}, 9 \mathrm{H},-\mathrm{Si}\left(\mathrm{CH}_{3}\right)_{2} \mathrm{C}\left(\mathrm{CH}_{3}\right)_{3}\right], 0.93$ [s, $9 \mathrm{H},-\mathrm{Si}-$ $\left.\left(\mathrm{CH}_{3}\right)_{2} \mathrm{C}\left(\mathrm{CH}_{3}\right)_{3}\right], 0.07\left[\mathrm{~s}, 6 \mathrm{H},-\mathrm{Si}\left(\mathrm{CH}_{3}\right)_{2} \mathrm{C}\left(\mathrm{CH}_{3}\right)_{3}\right], 0.06[\mathrm{~s}, 6 \mathrm{H}$, $\left.-\mathrm{Si}\left(\mathrm{CH}_{3}\right)_{2} \mathrm{C}\left(\mathrm{CH}_{3}\right)_{3}\right] \mathrm{ppm} .{ }^{13} \mathrm{C} \mathrm{NMR}\left(75 \mathrm{MHz}, \mathrm{CDCl}_{3}\right): \delta=159.0$, $131.3,129.2,129.0,128.9,113.6,80.3,71.2,70.5,60.0,55.1,40.6$, $37.5,25.9,25.9,25.7,24.0,18.2,18.1,10.1,9.6,-3.0,-4.2,-4.4$, -5.3 ppm. $[\alpha]_{\mathrm{D}}^{23.9}=-21.85\left(c=1.33, \mathrm{CHCl}_{3}\right)$. MS (EI): $\mathrm{m} / \mathrm{z}(\%)=$ $510\left[\mathrm{M}^{+}\right], 331,321,303,242,218,185,173,147,133,121$ (100), 101, 89, 73, 57. HRMS: $\mathrm{m} / z$ calcd. for $\mathrm{C}_{28} \mathrm{H}_{54} \mathrm{O}_{4} \mathrm{Si}_{2}$ : 510.3561, found 510.3578 .

The compound ( $305 \mathrm{mg}, 0.60 \mathrm{mmol}$ ) obtained was dissolved in a solution of $\mathrm{CH}_{2} \mathrm{Cl}_{2}$ and $\mathrm{pH} 7$ buffer solution (10:1)(11 mL). To this solution dichlorodicyanoquinone (DDQ) $(198 \mathrm{mg}, 0.87 \mathrm{mmol})$ was added at $0{ }^{\circ} \mathrm{C}$. The resulting solution was stirred at $0{ }^{\circ} \mathrm{C}$ for $1 \mathrm{~h}$. After filtration through the pad of Celite with $\mathrm{CH}_{2} \mathrm{Cl}_{2}(3 \times 10 \mathrm{~mL})$, the solution was concentrated. Purification by flash chromatography (hexane/EtOAc, 9:1) gave the desired alcohol 19a (173 mg, $74 \%$ ) as a colorless liquid. IR (film): $\tilde{v}=3438,2955,1471,1389$, $1360,1256 \mathrm{~cm}^{-1} \cdot{ }^{1} \mathrm{H}$ NMR $\left(300 \mathrm{MHz}, \mathrm{CDCl}_{3}\right): \delta=4.00(\mathrm{td}, J=$ 6.0, $3.0 \mathrm{~Hz}, 1 \mathrm{H}, \mathrm{CHOH}), 3.64\left(\mathrm{~m}, 2 \mathrm{H}, \mathrm{CH}_{2} \mathrm{OSi}\right) \mathrm{ppm} .3 .58$ (td, 1 $\mathrm{H}, J=5.9,3.0 \mathrm{~Hz}, \mathrm{CHOSi}$ ), 2.66 (br., $1 \mathrm{H}, \mathrm{CHOH}$ ), 1.72 (q, $2 \mathrm{H}$, $\left.J=6.3 \mathrm{~Hz}, \mathrm{CH}_{2} \mathrm{CH}_{2} \mathrm{OSi}\right), 1.59\left(\mathrm{~m}, 1 \mathrm{H}, \mathrm{CHCH}_{3}\right), 1.38-1.52(\mathrm{~m}, 2$ $\left.\mathrm{H}, \mathrm{CH}_{2} \mathrm{CH}_{3}\right), 0.90\left(\mathrm{t}, 3 \mathrm{H}, J=7.4 \mathrm{~Hz}, \mathrm{CHCH}_{3}\right), 0.86[\mathrm{~s}, 21 \mathrm{H}$, $\left.\mathrm{SiC}\left(\mathrm{CH}_{3}\right)_{3}, \mathrm{SiC}\left(\mathrm{CH}_{3}\right)_{3}, \mathrm{CHCH}_{3}\right], 0.06\left[\mathrm{~s}, 6 \mathrm{H}, \mathrm{Si}\left(\mathrm{CH}_{3}\right)_{2}\right], 0.00[\mathrm{~s}, 6$ $\left.\mathrm{H}, \mathrm{Si}\left(\mathrm{CH}_{3}\right)_{2}\right] .{ }^{13} \mathrm{C} \mathrm{NMR}\left(75 \mathrm{MHz}, \mathrm{CDCl}_{3}\right): \delta=76.9,75.4,60.7$, 40.2, 38.0, 28.6, 26.5, 18.8, 18.6, 11.1, 6.93, -3.20, -3.97, $-4.82 \mathrm{ppm}$. $[a]_{\mathrm{D}}^{25.5}=-12.94\left(c=1.48, \mathrm{CHCl}_{3}\right)$. MS $(\mathrm{EI}): \mathrm{m} / z(\%)=390\left[\mathrm{M}^{+}\right]$, 333, 303, 263, 241, 201, 189, 171, 147, 133, 109, 89, 73, 59. HRMS: $\mathrm{m} / z$ calcd. for $\mathrm{C}_{20} \mathrm{H}_{46} \mathrm{O}_{3} \mathrm{Si}_{2}: 390.2986$, found 390.2987.

$(1 R, 2 S, 3 S)-3-(t e r t-B u t y l d i m e t h y l s i l y l o x y)-1-e t h y l-2-m e t h y l-5-o x 0-$ pentyl 2-Bromopropanoate (20a): 2-bromopropionic acid $(111 \mu \mathrm{L}$, $1.23 \mathrm{mmol})$ and DMAP (40 mg, $0.33 \mathrm{mmol})$ was added to a solution of $19 \mathrm{a}(160 \mathrm{mg}, 0.41 \mathrm{mmol})$ in $\mathrm{CH}_{2} \mathrm{Cl}_{2}(5 \mathrm{~mL})$ at room temperature. After the solution was cooled to $0{ }^{\circ} \mathrm{C}, N, N$-dicyclohexylcarbodiimide ( $93 \mathrm{mg}, 0.45 \mathrm{mmol}$ ) was added. The resulting solution was stirred for $5 \mathrm{~min}$ at $0{ }^{\circ} \mathrm{C}$ before it was warmed to room temperature. After additional stirring for $30 \mathrm{~min}$ at room temperature, the precipitate was filtered. The filtrate was concentrated and purified by flash chromatography (hexane/EtOAc, 10:1). The desired bromoester was obtained as a colorless liquid (210 mg, 97\%). IR (film): $\tilde{v}=2928,2857,1737,1471,1387,1256,1222 \mathrm{~cm}^{-1} .{ }^{1} \mathrm{H}$ NMR (300 MHz, $\left.\mathrm{CDCl}_{3}\right): \delta=5.04[\mathrm{~m}, 1 \mathrm{H}, \mathrm{CHOC}(=\mathrm{O})], 4.33(\mathrm{~m}$, $\left.1 \mathrm{H}, \mathrm{BrCHCH}_{3}\right), 3.82(\mathrm{~m}, 1 \mathrm{H}, \mathrm{CHOSi}), 3.60\left(\mathrm{~m}, 2 \mathrm{H}, \mathrm{CH}_{2} \mathrm{OSi}\right)$, $1.84\left(\mathrm{~m}, 1 \mathrm{H}, \mathrm{CHCH}_{3}\right), 1.79\left(\mathrm{~d}, J=6.9 \mathrm{~Hz}, 3 \mathrm{H}, \mathrm{BrCHCH}_{3}\right), 1.62$ (m, $4 \mathrm{H}, \mathrm{CH}_{2} \mathrm{CH}_{3}, \mathrm{CH}_{2} \mathrm{CHOSi}$ ), 0.86-0.91 [m, $24 \mathrm{H}, \mathrm{CHCH}_{3}$, $\left.\mathrm{CH}_{2} \mathrm{CH}_{3}, \mathrm{SiC}\left(\mathrm{CH}_{3}\right)_{3}, \mathrm{SiC}\left(\mathrm{CH}_{3}\right)_{3}\right], 0.03$ (s, $\left.3 \mathrm{H}, \mathrm{SiCH} H_{3}\right), 0.01$ (s, 3 $\left.\mathrm{H}, \mathrm{SiCH}_{3}\right) \mathrm{ppm} .{ }^{13} \mathrm{C} \mathrm{NMR}\left(75 \mathrm{MHz}, \mathrm{CDCl}_{3}\right): \delta=170.0,78.3,70.6$, $59.9,41.3,41.1,26.2,25.9,22.1,18.5,10.6,10.0,-4.02,-4.99 \mathrm{ppm}$. $[a]_{\mathrm{D}}^{24.3}=-7.13\left(c=1.73, \mathrm{CHCl}_{3}\right) . \mathrm{MS}(\mathrm{EI}): \mathrm{m} / z(\%)=524\left[\mathrm{M}^{+}\right]$, $337,315,303,287,253,241,211,189,171,145,109,89,75$ (100), 59. HRMS: $m / z$ calcd. for $\mathrm{C}_{23} \mathrm{H}_{49} \mathrm{BrO}_{4} \mathrm{Si}_{2}$ : 524.2353, found 524.2334 .

The bromoester $(210 \mathrm{mg}, 0.40 \mathrm{mmol})$ obtained was dissolved in $\mathrm{MeOH}(2 \mathrm{~mL})$. To this solution DL-10-Camphorsulfonic acid (19 $\mathrm{mg}, 0.08 \mathrm{mmol}$ ) was added. The resulting solution was stirred at $0{ }^{\circ} \mathrm{C}$ for $1 \mathrm{~h}$. The reaction was terminated by addition of $\mathrm{Et}_{3} \mathrm{~N}$ $(56 \mu \mathrm{L}, 0.42 \mathrm{mmol})$. After the solution was concentrated, purification of the residue by flash chromatography (hexane/EtOAc, 5:1) gave the desired primary alcohol $(145 \mathrm{mg}, 88 \%)$ as a colorless liquid. IR (film): $\tilde{v}=3431,2928,1737,1257,1163,1060 \mathrm{~cm}^{-1} .{ }^{1} \mathrm{H}$ NMR (300 MHz, $\left.\mathrm{CDCl}_{3}\right): \delta=5.02[\mathrm{~m}, 1 \mathrm{H}, \mathrm{CHOC}(=\mathrm{O})], 4.36(\mathrm{~m}$, $\left.1 \mathrm{H}, \mathrm{BrCHCH}_{3}\right), 3.82(\mathrm{~m}, 1 \mathrm{H}, \mathrm{CHOSi}), 3.73\left(\mathrm{~m}, 2 \mathrm{H}, \mathrm{CH}_{2} \mathrm{OH}\right)$, $1.93\left(\mathrm{~m}, 2 \mathrm{H}, \mathrm{CH}_{2} \mathrm{CH}_{2} \mathrm{CHOSi}\right.$ ), 1.82 (dd, $J=7.0,1.9 \mathrm{~Hz}, 3 \mathrm{H}$,
$\left.\mathrm{BrCHCH}_{3}\right), 1.65\left(\mathrm{~m}, 3 \mathrm{H}, \mathrm{CH}_{2} \mathrm{CH}_{3}, \mathrm{CHCH}_{3}\right), 0.98(\mathrm{~d}, J=6.9 \mathrm{~Hz}$, $\left.3 \mathrm{H}, \mathrm{CHCH}_{3}\right), 0.90\left[\mathrm{~m}, 12 \mathrm{H}, \mathrm{CH}_{2} \mathrm{CH}_{3}, \mathrm{SiC}\left(\mathrm{CH}_{3}\right)_{3}\right], 0.09$ (s, $3 \mathrm{H}$, $\mathrm{SiCH}_{3}$ ), 0.07 (s, $\left.3 \mathrm{H}, \mathrm{SiCH}_{3}\right) \mathrm{ppm} .{ }^{13} \mathrm{C} \mathrm{NMR}\left(75 \mathrm{MHz}, \mathrm{CDCl}_{3}\right): \delta$ $=170.4,72.3,60.1,41.3,41.1,36.2,26.5,26.2,22.2,18.6,10.9$, $10.5,-3.75,-3.85$ ppm. $[\alpha]_{\mathrm{D}}^{24.4}=-0.80\left(c=1.08, \mathrm{CHCl}_{3}\right) . \mathrm{MS}(\mathrm{EI})$ : $\mathrm{m} / \mathrm{z}(\%)=410\left[\mathrm{M}^{+}\right], 213,201,189,173,145,127(100), 109,89,75$, 55. HRMS: $\mathrm{m} / z$ calcd. for $\mathrm{C}_{17} \mathrm{H}_{35} \mathrm{BrO}_{4} \mathrm{Si}$ : 410.1488 , found 410.1500 .

The alcohol (145 mg, $0.35 \mathrm{mmol})$ obtained above was dissolved in $\mathrm{CH}_{2} \mathrm{Cl}_{2}(2 \mathrm{~mL})$. To this solution was added Dess-Martin periodinane (DMP) $(179 \mathrm{mg}, 0.42 \mathrm{mmol})$ and stirred for $30 \mathrm{~min}$ at room temperature. After the reaction was completed, aqueous saturated $\mathrm{NaHCO}_{3}(5 \mathrm{~mL})$ was added and mixture was extracted with $\mathrm{CH}_{2} \mathrm{Cl}_{2}(3 \times 10 \mathrm{~mL})$. The organic layer was separated, dried $\left(\mathrm{MgSO}_{4}\right)$, and concentrated. Purification by flash chromatography (hexane/EtOAc, 7:1) offered the desired aldehyde 20a (131 mg, $91 \%)$ as a yellow liquid. ${ }^{1} \mathrm{H}$ NMR $\left(300 \mathrm{MHz}, \mathrm{CDCl}_{3}\right): \delta=9.77[\mathrm{~m}$, $1 \mathrm{H}, \mathrm{C}(=\mathrm{O}) H], 5.02\left(\mathrm{~m}, 1 \mathrm{H}, \mathrm{CHCH}_{2} \mathrm{CH}_{3}\right), 4.36[\mathrm{~m}, 1 \mathrm{H}, \mathrm{C}(=\mathrm{O})$ $\mathrm{CHBr}$, 4.15 (m, $1 \mathrm{H}, \mathrm{CHOSi}), 2.59$ (m, $\left.2 \mathrm{H}, \mathrm{CH}_{2} \mathrm{CHOSi}\right), 1.86$ $\left(\mathrm{m}, 1 \mathrm{H}, \mathrm{CHCH}_{3}\right), 1.80\left(\mathrm{dd}, J=6.9,1.3 \mathrm{~Hz}, 3 \mathrm{H}, \mathrm{BrCHCH}_{3}\right), 1.64$ $\left(\mathrm{m}, 2 \mathrm{H}, \mathrm{CH}_{2} \mathrm{CH}_{3}\right), 0.95\left(\mathrm{~d}, J=7.0 \mathrm{~Hz}, 3 \mathrm{H}, \mathrm{BrCHCH}_{3}\right), 0.85-$ $0.89\left[\mathrm{~m}, 12 \mathrm{H}, \mathrm{CH}_{2} \mathrm{CH}_{3}, \mathrm{SiC}\left(\mathrm{CH}_{3}\right)_{3}\right], 0.06\left(\mathrm{~s}, 3 \mathrm{H}, \mathrm{SiCH}_{3}\right), 0.02$ (s, $\left.3 \mathrm{H}, \mathrm{SiCH}_{3}\right) \mathrm{ppm} .{ }^{13} \mathrm{C} \mathrm{NMR}\left(75 \mathrm{MHz}, \mathrm{CDCl}_{3}\right): \delta=202,170,77.1$, $69.7,48.8,42.5,41.0,26.4,26.2,22.2,18.6,10.9,10.5,-3.82,-3.92$ ppm.

(6S,7S,8R)-6-(tert-Butyldimethylsilyloxy)-8-ethyl-4-hydroxy-3,7-dimethyl-1-oxacyclooctan-2-one (21a): Diiodomethane $(51 \mu \mathrm{L}$, $0.64 \mathrm{mmol}$ ) was added to a mixture of samarium (powder, $105 \mathrm{mg}$, $0.70 \mathrm{mmol})$ in THF $(3 \mathrm{~mL})$ at room temperature under nitrogen. Samarium(II) iodide was obtained as a blue-colored solution which was used after stirring for $2 \mathrm{~h}$. After the solution was cooled to $-78{ }^{\circ} \mathrm{C}$, a solution of the aldehyde $20 \mathrm{a}(130 \mathrm{mg}, 0.32 \mathrm{mmol})$ in THF $(2 \mathrm{~mL})$ was added under nitrogen. After the solution was stirred for $1 \mathrm{~h}$ at $-78^{\circ} \mathrm{C}$, it was warmed to room temperature and $0.1 \mathrm{M}$ $\mathrm{HCl}(5 \mathrm{~mL})$ was added. The mixture was extracted with diethyl ether $(3 \times 20 \mathrm{~mL})$. After the organic layer was washed with saturated sodium thiosulfate solution $(15 \mathrm{~mL})$ and saturated sodium chloride solution $(15 \mathrm{~mL})$, the ethereal solution was dried $\left(\mathrm{MgSO}_{4}\right)$ and concentrated. Purification of the residue by flash chromatography (hexane/EtOAc, 3:1) provided the desired lactone 21a as a yellow liquid [a 7:1 mixture of diastereomers; major compound: $R_{\mathrm{f}}$ $=0.24$ (hexane/EtOAc, $1: 1 ; 66 \mathrm{mg}, 63 \%$ ), minor compound: $R_{\mathrm{f}}=$ 0.15 (hexane/EtOAc, $1: 1 ; 9.4 \mathrm{mg}, 9.0 \%$ )]. The following data were obtained from the major compound. ${ }^{1} \mathrm{H}$ NMR $\left(500 \mathrm{MHz}, \mathrm{CDCl}_{3}\right)$ : $\delta=4.87[\mathrm{dd}, J=8.4,5.3 \mathrm{~Hz}, 1 \mathrm{H}, \mathrm{CHOC}(=\mathrm{O})], 4.04(\mathrm{dd}, J=9.1$, $4.7 \mathrm{~Hz}, 1 \mathrm{H}, \mathrm{CHOSi}), 3.57$ (m, $1 \mathrm{H}, \mathrm{CHOH}), 3.44$ (br., $1 \mathrm{H}$, $\mathrm{CHOH}), 3.15$ [dq, $J=9.4,6.3 \mathrm{~Hz}, 1 \mathrm{H}, \mathrm{C}(=\mathrm{O}) \mathrm{CHCH}_{3}$ ], 2.15 (ddd, $J=15.9,9.2,3.5 \mathrm{~Hz}, 1 \mathrm{H}, \mathrm{SiOCHCHCH}), 1.89(\mathrm{~m}, 1 \mathrm{H}$, one of $\left.\mathrm{CH}_{2} \mathrm{CH}_{3}\right), 1.84\left(\mathrm{~m}, 2 \mathrm{H}, \mathrm{CH}_{2} \mathrm{CHOH}\right), 1.49(\mathrm{~m}, 1 \mathrm{H}$, one of $\left.\mathrm{CH}_{2} \mathrm{CH}_{3}\right), 1.34$ [d, $\left.J=6.3 \mathrm{~Hz}, 3 \mathrm{H}, \mathrm{C}(=\mathrm{O}) \mathrm{CHCH}_{3}\right], 0.96(\mathrm{~m}, 3 \mathrm{H}$, $\left.\mathrm{SiOCHCHCH} H_{3}\right), 0.92\left[\mathrm{~s}, 9 \mathrm{H}, \mathrm{SiC}\left(\mathrm{CH}_{3}\right)_{3}\right], 0.89\left(\mathrm{~m}, 3 \mathrm{H}, \mathrm{CH}_{2} \mathrm{CH}_{3}\right)$, 0.12 (s, $\left.3 \mathrm{H}, \mathrm{SiCH}_{3}\right), 0.10$ (s, $\left.3 \mathrm{H}, \mathrm{SiCH}_{3}\right) \mathrm{ppm} .{ }^{13} \mathrm{C} \mathrm{NMR}(75 \mathrm{MHz}$, $\left.\mathrm{CDCl}_{3}\right): \delta=176.0,78.8,76.9,76.0,44.5,42.6,27.4,26.4,18.5$, $16.1,11.5,10.8,-4.1,-4.3 \mathrm{ppm}$. MS (EI): $m / z(\%)=330\left[\mathrm{M}^{+}\right], 287$, 257, 213, 201, 173, 159, 139, 115 (100), 99, 85, 75, 57. HRMS: $\mathrm{m} / \mathrm{z}$ calcd. for $\mathrm{C}_{17} \mathrm{H}_{34} \mathrm{O}_{4} \mathrm{Si}: 330.2226$, found 330.2244 .

(6S,7S,8R)-6-(tert-Butyldimethylsilyloxy)-8-ethyl-3,7-dimethyl-1-oxacyclooctane-2,4-dione (22a): Lactone 21a (55 mg, $0.17 \mathrm{mmol}$ ) obtained as described in the previous procedure (a 7:1 mixture of diastereomers) was dissolved in $\mathrm{CH}_{2} \mathrm{Cl}_{2}(2 \mathrm{~mL})$. To this solution was added Dess-Martin periodinane (DMP) (141 mg, $0.33 \mathrm{mmol}$ ). The resulting solution was stirred for $30 \mathrm{~min}$ at room temperature. 
After the reaction was completed, aqueous saturated $\mathrm{NaHCO}_{3}$ ( $5 \mathrm{~mL}$ ) was added and mixture was extracted with $\mathrm{CH}_{2} \mathrm{Cl}_{2}$ $(3 \times 10 \mathrm{~mL})$. The organic layer was separated, dried $\left(\mathrm{MgSO}_{4}\right)$, and concentrated. Purification of the residue by flash chromatography (hexane/EtOAc, 7:1) offered the desired compound 22a (48 mg, $88 \%$ ) as a yellow liquid (an 8:1 mixture of diastereomers). The major compound showed the following spectroscopic behavior. ${ }^{1} \mathrm{H}$ NMR (300 MHz, $\left.\mathrm{CDCl}_{3}\right): \delta=5.04$ [ddd, $J=8.6,4.6,4.4 \mathrm{~Hz}, 1 \mathrm{H}$, $\mathrm{CHOC}(=\mathrm{O})], 4.05$ (m, $1 \mathrm{H}, \mathrm{CHOSi}), 3.49$ [q, $J=6.7 \mathrm{~Hz}, 1 \mathrm{H}, \mathrm{C}(\mathrm{O})-$ $\left.\mathrm{CHCH}_{3}\right], 3.23$ [d, $J=11.8 \mathrm{~Hz}, 1 \mathrm{H}$, one of $\left.\mathrm{CH}_{2} \mathrm{C}(=\mathrm{O})\right], 2.71$ [t, $J$ $=11.2 \mathrm{~Hz}, 1 \mathrm{H}$, one of $\left.\mathrm{CH}_{2} \mathrm{C}(=\mathrm{O})\right], 1.89(\mathrm{~m}, 1 \mathrm{H}, \mathrm{SiOCHCHCH})_{3}$, 1.55-1.72 (m, $\left.2 \mathrm{H}, \mathrm{CH}_{2} \mathrm{CH}_{3}\right), 1.19[\mathrm{~d}, J=6.7 \mathrm{~Hz}, 3 \mathrm{H}, \mathrm{C}(=\mathrm{O})-$ $\left.\mathrm{CHCH}_{3}\right], 1.02$ (t, $\left.J=7.4 \mathrm{~Hz}, 3 \mathrm{H}, \mathrm{CH}_{2} \mathrm{CH}_{3}\right), 0.94$ (d, $J=4.9 \mathrm{~Hz}$, $\left.3 \mathrm{H}, \mathrm{SiOCCHCH} H_{3}\right), 0.81\left[\mathrm{~s}, 9 \mathrm{H}, \mathrm{SiC}\left(\mathrm{CH}_{3}\right)_{3}\right], 0.03\left(\mathrm{~s}, 3 \mathrm{H}, \mathrm{SiCH}_{3}\right)$, $0.00\left(\mathrm{~s}, 3 \mathrm{H}, \mathrm{SiCH}_{3}\right) \mathrm{ppm} .{ }^{13} \mathrm{C} \mathrm{NMR}\left(75 \mathrm{MHz}, \mathrm{CDCl}_{3}\right): \delta=202$, 172. 80.5, 71.7, 57.8, 45.5, 42.4, 26.2, 25.1, 18.6, 11.5, 11.1, 10.1, $-4.58,-4.64 \mathrm{ppm}$.

(6S)-4-Hydroxy-6-[(1S,2R)-2-hydroxy-1-methylbutyl]-3-methyl-5,6dihydro-2H-pyran-2-one (2a): A solution of lactone 22a (41 mg, $0.12 \mathrm{mmol}$ ) as obtained previously (an 8:1 mixture of diastereomers) in $\mathrm{HF} / \mathrm{CH}_{3} \mathrm{CN}\left[48 \% \mathrm{HF} / \mathrm{CH}_{3} \mathrm{CN}, 1: 19(\mathrm{v} / \mathrm{v})\right](1 \mathrm{~mL})$ was stirred for $1 \mathrm{~h}$ at room temperature. The reaction was terminated by addition of solid $\mathrm{CaCO}_{3}(30 \mathrm{mg})$. After the mixture was filtered with aid of Celite and washed by ether $(3 \times 10 \mathrm{~mL})$, the filtrate was concentrated. Purification by flash chromatography (hexane/EtOAc, 1:1 to 1:2) provided the desired lactone 2a $(15.5 \mathrm{mg}, 58 \%)$ as a white solid. Spectroscopic data were matched with those obtained previously.

Supporting Information (see also the footnote on the first page of this article): Experimental procedure for compounds $\mathbf{1 5 b}-\mathbf{1 7} \mathbf{b}, \mathbf{2 3 a}$, 19b-26b, 28-34.

\section{Acknowledgments}

This work is supported by the Korea Research Foundation Grant (KRF-2004-015-C00267).

[1] D. A. Hopwood, Chem. Rev. 1997, 94, 2465-2497.

[2] J. Staunton, B. Wilkinson, Chem. Rev. 1997, 97, 2611-2629.

[3] Y. Xue, D. H. Sherman, Nature 2000, 403, 571-574.

[4] Y. J. Yoon, B. J. Beck, B. S. Kim, H.-Y. Kang, K. A. Reynolds, D. H. Sherman, Chem. Biol. 2002, 9, 203-214.

[5] C. M. Kao, G. Luo, L. Katz, D. E. Cane, C. Khosla, J. Am. Chem. Soc. 1995, 117, 9105-9106.

[6] J. Cortés, K. E. H. Wiesmann, G. A. Roberts, M. J. B. Brown, J. Staunton, P. F. Leadlay, Science 1995, 268, 1487-1489.

[7] a) C. M. Kao, G. Luo, L. Katz, D. E. Cane, C. Khosla, J. Am. Chem. Soc. 1994, 116, 11612-11613; M. J. B. Brown, J. Cortés,
A. L. Cutter, P. F. Leadlay, J. Chem. Soc., Chem. Commun. 1995, 1517-1518; b) K. E. H. Wiesmann, J. Cortés, M. J. B. Brown, A. L. Cutter, J. Staunton, P. F. Leadlay, Chem. Biol. 1995, 2, 583-589; c) R. Piper, S. Ebert-Khosla, D. E. Cane, C. Khosla, Biochemistry 1996, 35, 2054-2060; d) G. Luo, R. Pieper, A. Rosa, C. Khosla, D. E. Cane, Bioorg. Med. Chem. 1996, 4, 995-999; e) . A. L. Wilkinson, U. Hanefeld, B. Wilkinson, P. F. Leadlay, J. Staunton, Tetrahedron Lett. 1998, 39, 9827-9830.

[8] B. J. Beck, Y. J. Yoon, K. A. Reynolds, D. H. Sherman, Chem. Biol. 2002, 9, 575-583.

[9] S.-J. Kim, H.-Y. Kang, D. H. Sherman, Synthesis 2001, 17901793.

[10] H.-H. Yang, E.-S. Kim, Y. J. Yoon, H.-Y. Kang, Bull. Korean Chem. Soc. 2006, 27, 473-474.

[11] B. J. Beck, C. C. Aldrich, R. A. Fecik, K. A. Reynolds, D. H. Sherman, J. Am. Chem. Soc. 2003, 125, 12551-12557.

[12] a) G. A. Molander, J. B. Etter, L. S. Harring, P. Thorel, J. Am. Chem. Soc. 1991, 113, 8036-8045; b) H. B. Kagan, J. L. Namy, P. Girard, Tetrahedron 1981, 37, 175-180; c) T. Mukaiyama, I. Shina, H. Iwadare, M. Saitoh, T. Nishimura, N. Ohkawa, H. Satoh, K. Nishimura, Y. Tani, M. Hasegawa, K. Yamada, K. Saitoh, Chem. Eur. J. 1999, 5, 121-161; d) S. Inoue, Y. Iwabuchi, H. Irie, S. Hatakeyama, Synlett 1998, 735-736; e) T. Takemura, Y. Nishii, S. Takahashi, J. Kobayashi, T. Nakata, Tetrahedron 2002, 58, 6359-6365; f) P. P. Reddy, K. F. Yen, B. J. Uang, J. Org. Chem. 2002, 67, 1034-1035; g) M. Inoue, M. Sasaki, K. Tachibana, J. Org. Chem. 1999, 64, 9416-9429; h) M. Inoue, M. Sasaki, K. Tachibana, Tetrahedron 1999, 55, 10949-10970; i) M. Inoue, M. Sasaki, K. Tachibana, Tetrahedron Lett. 1997, 38, 1611-1614; j) S. Ichikawa, S. Shuto, N. Minakawa, A. Matsuda, J. Org. Chem. 1997, 62, 1368-1375; k) M. Inoue, M. Sasaki, K. Tachibana, Angew. Chem. Int. Ed. Engl. 1998, 37, 965-969; 1) M. Inoue, M. Tachibana, K. Sasaki, J. Org. Chem. 1999, 64, 9416-9429.

[13] a) S.-i. Fukuzawa, H. Matsuzawa, S.-i. Yoshimitsu, J. Org. Chem. 2000, 65, 1702-1706; b) S.-i. Fukuzawa, M. Tatsuzawa, K. Hirano, Tetrahedron Lett. 1998, 39, 6899-6900.

[14] We first tried the protection of the free hydroxy group of 14a. However, we were not able to protect the free secondary hydroxy group with the PMB group. Therefore, we have decided to use the aldehyde 13b for the asymmetric Reformatsky reaction to prepare $\mathbf{3}$.

[15] For reported examples for translactonization by deprotection of the silyl groups, see: a) P. T. O'Sullivan, W. Buhr, M. A. M. Fuhry, J. R. Harrison, J. E. Davies, N. Feeder, D. R. Marshall, J. W. Burton, A. B. Holmes, J. Am. Chem. Soc. 2004, 126, 2194-2207; b) M. S. Congreve, A. B. Holmes, A. B. Hughes, M. G. Looney, J. Am. Chem. Soc. 1993, 115, 5815-5816.

[16] W. C. Still, M. Kahn, A. Mitra, J. Org. Chem. 1978, 43, $2923-$ 2925.

Received: March 22, 2007 Published Online: May 11, 2007 